\title{
Compensation for Takings: An Economic Analysis
}

\author{
Lawrence Blume $\dagger$ \\ and \\ Daniel L. Rubinfeld $† \dagger$
}

I

INTRODUCTION

A. Regulatory Takings and Just Compensation

The fifth amendment to the United States Constitution prohibits the government from taking private property for public use without just compensation. ${ }^{1}$ Prior to the landmark decision in Pennsylvania Coal Co. v. Mahon, ${ }^{2}$ physical imvasion was necessary for such a "taking" to occur. ${ }^{3}$ However, im Pennsylvania Coal, ${ }^{4}$ Justice Holmes stated for the Court: "The general rule at least is, that while property may be

$\dagger$ Associate Profcssor of Econonics, University of Michigan. B.A. 1973, Washington University; Pl.D, 1977, University of California, Berkeley.

t† Professor of Law and Professor of Economics, University of California, Berkeley. B.A. 1967, Princeton University; M.S. 1968, Ph.D. 1972, Massaclsusetts Institute of Technology.

This researcl is supported in part by the Law and Economics program at the University of Micligan and in part by the Center for Real Estate and Urban Economics at the University of California, Berkeley. Nina Gillman and Ann Parrent provided helpful research assistance. Andrea Peterson provided extensive substantive and editorial comments on several drafts of the manuscript. The authors benefited substantially from comments made at seminars given at Toronto, Nortliwestern, Columbia and Berkeley law schools. In addition, Bruce Ackerman, Robert Ellickson, Richard Epstein, Richard Lempert, Joseph Sax, aud Jan Vetter provided interesting and constructive arguments. All views withm are, of course, our own, and not necessarily those of these commentators.

1. The fifth amendment to the U.S. Constitution provides: "[N]or shall private property be taken for public use, without just compeusation." U.S. CoNST. amend. V. This requirement applies directly to the federal government and is applied to the states througli the due process clause of the 14th amendment. See Webb's Fabulous Pliarmacies, Inc. v. Beckwith, 449 U.S. 155, 160 (1980); Chicago, B. \& Q.R.R. v. Clicago, 166 U.S. 226, 235-41 (1897). In addition, virtually all state constitutions require compensation when property is taken; 23 state constitutions go further and require compensation when property is taken or dainaged. See L. TrIBE, AMERICAN ConstrTUTIONAL LAW $\$ 9-2$, at 458 n.6 (1978).

2. 260 U.S. 393 (1922).

3. A brief summary of the development of the takings doctrine is given in Berger, $A$ Policy Analysis of the Taking Problem, 49 N.Y.U. L. REv. 165 (1974).

4. In Pennsylvania Coal, the Malions owned a home located on land under which the Pennsylvania Coal Company had reserved the riglit to mine for coal witlout liability for dainages. 260 U.S. at 412. A new Pennsyivania statute forbade coal mining that caused subsidence of residences, and the Mahons urged that the no-liability provision was no longer valid. The Pennsylvania Supreme Court agreed, holding that the statute was a legitinate exercise of the 
regulated to a certain extent, if regulation goes too far it will be recognized as a taking."5 Although the Court only invalidated the statute and did not require that Pennsylvania pay coinpensation, language in the opinion raised the possibility that, in an appropriate case, ${ }^{6}$ the regulation would stand but the payment of just compensation would be ordered.

Since its decision in Pennsylvania Coal, the Court has had diffculty deciding when regulations "go too far," and has yet to articulate a clear standard for determining when sucl government activity should be considered a taking of property. ${ }^{7}$ Moreover, absent physical invasion, the Court has generally held that regulations affecting real property are legitnnate exercises of regulatory powers that do not require compensation. ${ }^{8}$

However, on soine occasions in which physical invasions have not been involved, the courts have found that regulation has gone too far and constitutes a taking. In these situations, often called regulatory takings, lower courts have ordered compensation, usually in the form of interim damages. ${ }^{9}$ Moreover, these courts have invalidated the regulations, giving government the option either to stop regulating or to pursue its regulatory objectives by exercismg its eminent domain power. If and when the government does invoke the power of eminent domain, permanent damages inust be paid. While many lower courts have recognized the role of interim damages in regulatory takings, ${ }^{10}$ the Supreine Court has sometinies resisted expanding the role of coinpen-

police power, and directed a decree for the Mahons. The coal company then brought the case to the Supreme Court on a writ of error. Id.

5. Id. at 415 (emphasis added).

6. Pennsylvania Coal may have been an mappropriate case, since the State of Pennsylvania was not a party to the action.

7. Tests other than physical invasion that have been applied at various times by the courts mclude: (l) diminution in value, im which a taking depends on the extcnt of economic loss caused by government action, and (2) noxious use, in which a government regulation, designed to regulate an owner's harmful use of his property, is not considered a taking. A more recent and more complex approach, which rejected both of the above, was taken in Penn Cent. Transp. Co. v. New York City, 438 U.S. 104 (1978). For discussion of these tests, see R. ElliCkson \& A. TARLOCK, Land Use Controls-Cases and Materials 133-38 (1981).

8. Unless explicitly stated otherwise, our analysis is limited to takings involving real property.

9. Interim damages compensate the landowner for losses incurred between the time of enactment of the regulation and the tine at which the regulation is either removed or made permanent through the exercise of the eminent domain power. Justice Brennan discusses interim damages in his dissent in San Diego Gas \& Elec. Co. v. City of San Diego, 450 U.S. 621,637 (1981) (Brennan, J., dissenting). For a more general discussion see R. ELLICKSON \& A. TARLOCK, supra note 7, at 158-76. Our discussion focuses on the compensation rather than the invalidation question, so the payment of interim damages is important.

10. See, e.g., Sixth Camden Corp. v. Township of Evesham, 420 F. Supp. 709 (D.N.J. 1976); Prince George's County v. Blumberg, 44 Md. App. 79, 407 A.2d 1151 (1979); City of Austin v. Teague, 570 S.W.2d 389 (Tex. 1978). 
sation in takings cases. However, Justice Brennan's strong dissent, ${ }^{11}$ and the supportive concurring opinion of Justice Rehnquist, ${ }^{12}$ in San Diego Gas \& Electric Co. v. City of San Diego ${ }^{13}$ signal that the Court may be ready to expand the role of coinpensation beyond physical invasion to include regulatory takings. ${ }^{14}$

Support for compensation for regulatory takings has also increased among scholars, ${ }^{15}$ and many econornic and noneconomic perspectives on coinpensation for regulatory takings have been developed. ${ }^{16}$ However, relatively hittle has been written on the role of compensation as a form of insurance against regulatory risks. ${ }^{17}$ This Article provides an economic analysis of compensation as a form of imsurance and evaluates the efficiency arguments both for and against compensation.

\section{B. Compensation as Insurance Against Regulatory Takings}

This Article discusses neither the history and current state of takings jurisprudence, nor specific forms of regulatory takings. Rather, we adopt the goal of economic efficiency, and attempt to determine when compensation for regulatory takings will be consistent with that goal. ${ }^{18}$ From this perspective, a government's decision to "take" property is best seen in light of the efficient distribution of costs associated with land use regulation. In other words, the cost nnay be borne solely by the landowners harmed by the regulatory action, or it may be distributed across some or all of the taxpayers in the jurisdiction. In the latter case, the payinent of compensation may be conceived as insurance agamst the adverse effects of government regulation. ${ }^{19}$

11. 450 U.S. 621, 637 (1981) (Brennan, J., dissenting).

12. 450 U.S. 621, 633 (1981) (Rehnquist, J., concurring); see infra note 36.

13. 450 U.S. 621 (1981).

14. See infra text accoinpanying notes 34-39 for a more detailed discussion of the inplications of San Diego Gas \& Electric for compensation in regulatory takings.

15. The case for a damages remedy is made in Comment, Just Compensation or Just Invalidation: The Availability of a Damages Remedy in Challenging Land Use Regulations, 29 U.C.L.A. L. Rev. 711 (1982). See also Gordon, Compensable Regulatory Taking: A Tollbooth Rises on Regulation Road, 12 REAL Est. L.J. 211 (1983); Kmiec, Regulatory Takings: The Supreme Court Runs Out of Gas in San Diego, 57 IND. L.J. 45 (1982); Meyer \& Dolle, Changing Compensation Rules for Property Takings, 11 ReAL Est. Rev. 28 (1981).

16. See, e.g., Michelman, Property, Utility and Fairness: Comments on the Ethical Foundations of "Just Compensation" Law, 80 HARv. L. Rev. 1165 (1967); Sax, Takings and the Police Power, 74 YALE L.J. 36 (1964) [heremafter cited as Poliee Power]; Sax, Takings, Private Property and Public Rights, 81 YAle L.J. 149 (1971) [lereinafter cited as Private and Public].

17. The insurance argument for compensation developed in this paper was previously suggested in B. Ackerman, Private Property and the Constitution 45 (1977).

18. We are assuning that compensation will be paid if there is a taking.

19. Admittedly, the normative conclusions that we ultimately draw will be of greatest interest to those who value the goal of economic efficiency from which those conclusions follow. Nevertheless, even those who do not view efficiency as the sole or primary goal may find something of 
Generally, the risks associated with changes in regulatory policies impose costs on investors. These costs nay force investors to forego investments with high returns. Although one might expect investors to avoid the costs associated with risk by obtaining insurance in the private market, such insurance is not available because of market failure. Thus, government-provided insurance represents a potentially attractive alternative. However, for reasons related to private market failure, government-provided insurance must be offered after the fact (ex post) in the form of compensation for regulatory takings, rather than before the fact (ex ante). ${ }^{20}$

Therefore, the economic efficiency approach stresses the benefits and the costs of requiring compensation for a regulatory taking. Part II of this Article first reviews the recent takings cases and commentary, and introduces the efficiency approach to the takings question. Part III discusses the economic efficiency approach in greater detail. In particular, we explore the conditions under which coinpetitive markets will yield efficient outconnes. The initial premise of the market approach is that efficiency is achieved only where coinpetitive inarkets exist for all goods and commodities, including insurance. However, private insurance inarkets have failed to provide coverage against the risk of government actions such as zoning regulations. Given this market failure, it inay be appropriate for government to provide such insurance in the form of coinpensation. ${ }^{21}$ Part IV discusses the implementation of such a compensation scheme, in light of the adininistrative costs of compensation. Furthermore, the feasibility of direct government insurance sold to individuals, as an alternative to insurance through compensation, is considered. The appropriate amount of compensation, partial versus full compensation, and the problem of ineasuring losses in mar-

value in the analysis. First, although faimess approaches are not explicitly addressed, we suggest in passing that soine efficiency arguinents for compensation coincide with arguinents of fairness. Second, those theorists who accept efficiency as one value among others require an efficiency analysis of compensation as part, if not the entirety, of their theories. Finally, even those who base their theories entirely on grounds other than efficiency may find the proposed analysis useful in evaluating the econornic costs and benefits of their proposals. In general, even if one does not accept the normative conclusions of an efficiency analysis, one may want to know the economic costs of adopting a proposed compensation rule, or to compare the costs and benefits of competing mles. Thus, the efficiency analysis developed herein can be employed to determine the resource costs involved when courts enforce a nonefficient coinpensation rule.

20. There are, of course, a number of inportant hinitations on the use of compensation for insurance purposes. They relate to the cost of raising revenue and the possible distortional impact of compensation on private as well as governmental behavior. See infra Part Vl.

21. Whether or not coinpensation for market failure is appropriate depends upon the tradeoff between the cost of inarket failure, and the possible costs associated with either poor dcsign and ineffective administration of a compensation program, or a program which serves the intercsts of government bureaucrats, but not the inore general interest of the public. Hereafter government action that imposes these costs is called "governinent failure." 
ket value are examined in Part V. Part VI focuses on government failure, and suggests that "fiscal illusion" 22 sometimes justifies the payment of compensation. This Article concludes that economic efficiency recominends compensation in those cases that entail relatively large losses to those unable to insure against such losses. Yet even in the presence of "fiscal illusion," not all regulatory actions ought to require compensation. Thus, the imsurance perspective envisions an expanded scope of compensation for regulatory takings. ${ }^{23}$

\section{II}

\section{A Brief Review of Cases and Commentaries}

The success of plaimtiffs seeking monetary damages in inverse condemnation ${ }^{24}$ proceedings has been rare. Damages have usually been limited to those cases in which there has been a physical invasion of the land. When land values are affected by regulation and physical invasion is not involved, this remedy has generally not been available. ${ }^{25}$

However, the compensation reinedy has relatively recently achieved further acceptance by the courts in cases not involving physical invasion. The Supreme Court's view on the matter has yet to be clearly defined, but the Court's willingness to support an expansive role for compensation has imcreased over time, as the following brief summary of the more important cases suggests.

22. "Fiscal illusion" describes the tendency of the government to discount any social costs associated with a project or decision that are not reflected directly in budgetary outlays.

23. Because of the complexity of the analysis which follows, the arguments are developed sequentially, adding dimensions to the discussion as the analysis progresses. Thus, the initial discussion of the insurance argument makes a number of restrictive assumptions about the environment in which the taking occurs. This permits the presentation of the basic argument. The sequential relaxation of assumptions allows one to see some of the subtleties of the argument without getting lost in economic details.

An example is the assumption that the government decision to regulate is inade in a "socially desirable" manner independent of the compensation rule which has been selected. This allows us to set aside the potential beneficial or adverse effects of compensation on the functioning of the local government regulator. In Part V of the Article we relax this assumption and concentrate specifically on the decisionmaking of the local government and how it is affected by the compensation rule.

24. According to Justice Brennan:

The phrase "inverse condenmation" generally describes a cause of action against a government defendant in which a landowner may recover just compensation for a "taking" of his property under the Fifth Amendment, even though formal condemnation proceedings in exercise of the sovereign's power of emment domain have not been instituted by the government entity. . . . In an "mverse condemnation" action, the condemnation is "inverse" because it is the landowner, not the government entity, who institutes the proceeding.

San Diego Gas \& Elec. Co. v. City of San Diego, 450 U.S. 621, 638 n.2 (1981) (Brennan, J., dissenting) (citations omitted).

25. See R. Ellickson AND A. TARLOCK, supra note 7, at 151-90. 


\section{A. Compensation and Regulatory Takings: The Supreme Court}

\section{The Physical Invasion Approach: Inconsistency and Uncertainty}

Although the physical invasion approach to the determination of liability might appear to be a bright-line standard that is easily admmistered, it is not without difficulties. These difficulties explain in part the inconsistent decisions of the Court, and the recent support for compensation in regulatory-taking cases.

For example, in United States $v$. Causby, ${ }^{26}$ the Court found that airplane flights less than 100 feet above a chicken farm constituted a taking. The Court found the overflights a physical invasion even though the government had never physically touched or seized the land. Causby, however, can be distinguished from typical physical mvasion cases. The diminution of market value that resulted from the physical invasion was not substantial; most of the decline in value resulted from the noise that the airplanes caused. Moreover, the rationale for the decision is not entirely clear. The Court may liave based its decision to award coinpensation on the invasion itself or on the consequences of the invasion. After Causby, it is unclear what acts short of an actual physical invasion will nevertheless constitute a taking.

More recently, the Court distinguished between temporary and permanent physical invasions. In Loretto $v$. Teleprompter Manhattan $C A T V$ Corp. ${ }^{27}$ the Court held that a taking occurs whenever there is a permanent physical invasion. ${ }^{28}$ However, the Court did not address the compensation aspect of temporary physical invasions. ${ }^{29}$ Loretto supports the view that the nature of the physical invasion ought to be the primary, if not the sole, determinant of whether a taking lias occurred. ${ }^{30}$ However, the Court lias never specified the determining factors in a taking case.

Indeed, in Penn Central Transportation Co. v. New York City, ${ }^{31}$ the Court stressed that it could not devise a set formula for determining when a regulatory taking has occurred. The Court did, liowever, sug-

26. 328 U.S. 256 (1946).

27. 102 S. Ct. 3164 (1982).

28. Id. at 3171 . The Court assumed that compensation was the appropriate remedy, but remanded for a determination of the proper amount of compensation.

29. Id. at 3172 .

30. The question whether physical mvasion should be the primary determinant of a taking is far from settled. See Costonis, Presumptive and Per Se Takings: A Decisional Model for the Taking Issue, 58 N.Y.U. L. REV. 465, 501-23 (1983). The concept of physieal invasion was developed in cases such as United States v. Causby, 328 U.S. 256 (1946), see supra text accompanying note 26, and Batten v. United States, 306 F.2d 580 (10th Cir. 1962), cert. denied, 371 U.S. 955 (1963), in which the court held that no taking had occurred with respect to property only near and not under the flight path.

31. 438 U.S. 104 (1978). 
gest a set of factors that are relevant. For example, the more extensive the adverse economic impact and the more the government activity interferes "with distinct investment-backed expectations," the more likely that a taking will be found. ${ }^{32}$ And, a taking is inore likely to be found if the "interference with property can be characterized as a physical invasion by government." 33

Thus, the current state of the case law leaves doubt as to when a taking will be declared. It is also still unclear whether compensation is available only in cases involving physical invasion, or whether physical invasion is but one of several factors to be considered. However, a recent decision of the Supreme Court lends support to the latter interpretation.

\section{New Hope for Compensation for Regulatory Takings: San Diego Gas \& Electric Company v. City of San Diego}

The prospects for an expanded role for compensation took a positive turn in San Diego Gas \& Electric Co. v. City of San Diego. ${ }^{34}$ In 1966, the San Diego Gas \& Electric Company purchased land as a future site for a nuclear power plant. The City of San Diego later rezoned some of the land for agricultural and open-space use. The utility company sued in an inverse condemnation proceeding. The majority of the Court avoided the takings question by ruling that the Court lacked jurisdiction over the case since a final judgment had not been entered $\mathrm{m}$ the state court proceeding. ${ }^{35}$ However, the dissenting opinion written by Justice Brennan, and joined by three justices, appears to provide strong support for compensation in cases involving regulatory takings. ${ }^{36}$

According to Justice Brennan, "Invalidation unaccompanied by payinent of damages would hardly compensate the landowner for any economic loss suffered during the tinne his property was taken." ${ }^{\text {37 }}$ The fact that there were four minority votes and one supportive majority vote is promising for those desiring an expanded role for coinpensa-

32. Id. at 124 .

33. Id. The court did not concern itself directly with whether compensation or invalidation was the appropriate reinedy if a taking were found.

34. 450 U.S. 621 (1981).

35. Id. at $623,632-33$.

36. Id. at 637-61 (Brennan, J., dissenting). Justice Blackmun's inajority opinion is partially supportive of the Brennan position, although somewhat vague.

In his concurring opinion, Justice Rehnquist stated: "If I were satisfied that this appeal was from a 'final judgment or decree' of the California Court of Appeal, as that term is used in 28 U.S.C. $\$ 1257$, I would have little difficulty in agreeing with much of what is said in the dissenting opinion of Justice BRENNAN." Id. at 633-34 (Rehnquist, J., concurring).

37. Id. at 655 (Brennan, J., dissenting) (footnote ornitted). 
tion. ${ }^{38}$ Moreover, the current mood of some commentators and the decisions of some lower courts suggest that support for compensation in nonphysical invasion cases is strong. ${ }^{39}$

\section{B. Compensation and Regulatory Takings: Alternative Approaches}

In addition to the physical invasion approach discussed above, a number of other theories or approaches to the related questions of liability and compensation for regulatory takings have been advanced. All of these prominent takings theories can be criticized. They are difficult to apply, suffer from internal conceptual problems, and tell us hittle or nothing about the appropriate remedy for a regulatory taking.

One common approach to the taking question recominends compensation whenever regulation results in a substantial diminution of the value of the property. ${ }^{40}$ Froin this perspective, no liabihty exists if a regulation affects the value of the property in only a minor way. On the other hand, compensation should be available where government action destroys most of the value of the property. ${ }^{41}$

38. See supra note 36 . In his dissent, Justice Brennan specified the nature of his argument for the payment of interim damages. He stated:

In my view, once a court establishes that there was a regulatory "taking," the Constitution demands that the government entity pay just compensation for the period commencing on the date the regulation first effected the "taking," and ending on the date the government entity chooses to rescind or otherwise amend the regulation.

The fact that a regulatory "takmg" may be temporary, by virtue of the government's power to rescind or amend the regulation, does not make it any less of a constitutional "takmg."

Ordinary principles determming the proper measure of just compensation, regularly applied in cases of permanent and temporary "takings" involving formal condemnation proceedings, occupations, and plrysical invasions, should provide guidance to the courts in the award of compensation for a regulatory "taking."

450 U.S. at 653, 657, 658-59 (Brennan, J., dissenting) (footnotes omitted).

39. One recent commentary which provides a useful summary of the inverse condemnationcompensation issue is Krier, The Regulation Machine, 1 SuP. CT. ECoN. REv. 1 (1982). Courts that have followed the imclinations of the minority position in San Diego include Martino v. Santa Clara Valley Water Dist., 703 F.2d 1141 (9th Cir. 1983); Shamrock Dev. Co. v. City of Concord, 656 F.2d 1380, 1384 (9th Cir. 1981); Hernandez v. City of Lafayette, 643 F.2d 1188 (5th Cir. 1981); Jentgen v. United States, 657 F.2d 1210 (Ct. Cl. 1981); Burrows v. City of Keene, 121 N.H. 590, 432 A.2d 15 (1981); and Zinn v. State, 112 Wis. 2d 417, 334 N.W.2d 67 (1983).

40. See Justice Holmes' opimion in Pennsylvania Coal Co. v. Mahon, 260 U.S. 393, 413 (1922).

41. In Penn Cent. Transp. Co. v. New York City, 438 U.S. 104 (1978), the Court appeared to reject the substantial diminution in value approach. Id. at 131. The Landmarks Preservation Commission designated Grand Central Station a historical landnuark. Id. at 115-16. Plaintiffs argued that the designation caused a substantial diminution in the value of the site, because it restricted permissible alterations and further developnent. However, the plaintiffs were given partial compensation by the city in the form of transferable development rights. To the extent that Penn Central had not fully developed the landmark site as permitted by applicable zoning laws, relevant ordinances permitted Penn Central to transfer those unused developinent rights to nearby parcels. Id. at 113-14. These valuable transferable development rights reduced the economic 
Although the diminution in value approach has had some success in the lower courts, it is not easily applied to regulatory takings. ${ }^{42}$ The most obvious difficulty is determining which losses in the value of the land are "substantial." Moreover, it is unclear whether the courts should account for lost "subjective" value which is not recognized by the market. Courts inust also decide whether to compensate based on the nature of the government activity, or based on the availability of private-market insurance.

The noxious use approach proposes that government may regulate an activity without liability-despite substantially diminishing the value of the property-where the activity is deemed to be noxious or harmful to the health and safety of the public., ${ }^{43}$ Under this approach, compensation is not required in situations involving conflicting land use when one of the activities is improper.

However, the noxious use approach is flawed, in part because of the difficulty in determining whicls uses are noxious, and in part because the interests of the imdividual landowners are not taken imto account. The noxious use approach leaves many questions unanswered: Were the landowners aware of the likelihood of government regulation? Were they prepared to accept the risks that regulation imposes on them? Were these risks foreseeable?

A novel approach to the takings question, suggested by Professor Sax, proposes that government purposes are relevant to the coinpensation decision. In the first of his two articles on the subject, Sax argues that compensation sliould be required only in situations where the government acts as an enterprise organization. ${ }^{44}$ In such situations, tlie government is not balancing the benefits of competmg claims to use the land; rather, it is acting as as private business producing goods and services. Compensation limits the otherwise unrestrained use of governmental powers, because it alters the incentives facing regulatory bodies and forces them to take into account the cost of land resources that they use. $^{45}$

harm associated with the frustration of the plaintiff's investunent-backed expectations. In other words, the designation caused substantial diminution in value, but the net value of the loss, taking account of the transferable development rights, may not have been great. Thus, the opinion at least leaves in doubt how the Court would rule in a case in which a substantial diminution in value was the predominating factor.

42. For a discussion of the diminution in value approach, see Berger, supra note 3, at 175-77.

43. The noxious-use terminology is based upon Professor Freund's distinction between regulations aimed at preventing harms (with no compensation paid) and regulations aimed at extracting benefits (compensation paid). See E. FreUNd, The Police Power 546-47 (1904).

44. Police Power, supra note 16 , at 63 . This is usually called the enterprise-arbitral test. See, e.g., Berger, supro note 3, at 177-79.

45. Police Power, supra note 16, at 64-67. We returu to this issue and its efficiency inplications in Part V. 
In a subsequent article, Professor Sax goes even further, proposing that compensation should be paid only if there are no "spillovers" or "externahities" in the conduct that the government is regulating. ${ }^{46}$ Such externalities arise when the actions of one actor, a firm or individual, affect the well-being of another actor (the utility of an individual or the profits of a firm) who is not directly engaged in the activity. These external effects or spillovers are not accurately reflected in the market through the price of goods and services. ${ }^{47}$ However, since most regulatory activity attempts to control such externalities, this approach awards compensation only in a narrow set of circumstances.

The two positions taken by Professor Sax suffer from the same fiaw that mars the noxious use approach. The government improves social welfare in one sense when it regulates otherwise harmful externalities. But all regulatory policies contain an implicit rule for the distribution of the social gain they create. Whenever the government regulates a noxious activity on a particular piece of land, many members of society will benefit. But the landowner who undertook the noxious activity will lose by the regulation. If the regulation is in fact socially beneficial, it would be possible to redistribute some of the gains from those who benefit to the landowner, so that everyone is better off, or at least so that some are better off and no one is worse off. The landowner is prevented from sharing in this social gain when there is no redistribution. Thus, the compensation issue is more a question of distributing the costs and benefits created by government regulation. Yet, Sax fails to analyze all of the efficiency implications of the alternative distributional schemes.

In a provocative article, Professor Michelman discusses the appropriate role of compensation froin a different perspective. ${ }^{48}$ He claims that the relevant variables should be the efficiency gains associated with the land use regulation, the costs of settlement ${ }^{49}$ if compensation is paid, and the deinoralization $\operatorname{cost}^{50}$ to society if no compensation is

46. Private and Public, supra note 16 , at 155-72.

47. Economists distinguish between economic externalities: the "true" extcrnality defined in the text, and pecuniary externalities in which the actions of one actor affect other actors, but the values associated with these effects are refiected in the inarket. For one useful discussion of this issue, see R. Tresch, Public Finance: A Normative Theory ch. 5 (1981).

48. Michelman, supra note 16 .

49. Id. at 1214-18. Settlement costs corrcspond roughly to the administrative costs of determining coinpensation.

50. Michelman defines demoralization costs as the:

total of (1) the dollar value necessary to offset disutihities which accrue to losers and their sympathizers specifically from the realization that no compensation is offered, and (2) the present capitalized dollar value of lost future production (reflecting either inpaired incentives or social unrest) caused by demoralization of uncompensated losers, their syinpathizers, and other observers disturbed by the thought that they themselves may be subjected to similar treatment on some other occasion. 
paid. According to Michelman, demoralization costs are distimct from efficiency costs, and they arise from the risks imposed by the threat of government regulation. In other words, individuals will not enter into a productive activity simply because of the increased risk associated with uncompensated government regulation. ${ }^{51}$

Given this analytical framework, Michelman argues that regulation should be undertaken without compensation where the efficiency gains outweigh the lesser of settlennent and deinoralization costs. ${ }^{52}$ Michelman also proposes a fairness rule for evaluating the compensation question, arguing that a decision is fair if the individual plaintiff realizes that he and others like him would be better off in a society in which compensation is not paid..$^{53}$

The Michelman approach does analyze the question of liability from a broad perspective that responds to efficiency concerns. However, Michelman's analysis of demoralization and settlement costs is somewhat sketchy, and the efficiency implications of that analysis are not clear. For example, Michelman never states exphicitly which of his categories ought to include the cost of calculating the cost-benefit tradeoff. In addition, the number of individuals likely to be demoralized and the extent of the damage involved is never pragmatically treated.

The analysis in this Article cannot hope to resolve fully all of the conflicts in current takings theories, or to answer all of the questions raised above. In limiting our analysis to the efficiency issue, we do not treat the legal consistency of the efficiency approach with the fifth amendment. Nor do we extensively consider impleinentation probleins. We will attempt to show, lowever, that the theme of risk bearing and insurance is either explicit or implicit in a number of cases and commentaries. Application of the efficiency approach to takings deserves serious attention.

\footnotetext{
Id. at 1214 (footnotes omitted).

51. Our analysis will suggest that some of these costs can be avoided by compensation, especially in those cases in which individuals cannot otherwise insure themselves.

52. Michelman, supra note 16, at 1215. Michelman's approach can be criticized from an economic perspective because it does not consider partial compensation as a policy option. One can easily imagine that partial, but not total, compensation would be sufficient to minimize the sum of demoralization and settlement costs.

53. Michelman, supra note 16, at 1218-24. From an economic perspective, Michelman's analysis raises mteresting questions about the role of compensation as insurance. Demoralization costs arise, after all, because individuals other than those directly affected by the regulation do not wish to bear the risk associated with uncompensated takings. One might argue (although Michelman does not) that fairness necessitates compensation only when the individual harmed would have gone to some effort and expense to avoid bearing the risk of regulation. Of course, others might respond that it is unfair for individuals not to be compensated when others benefit at their expense, or that individuals might not exert effort if they are poorly informed about insurance or have insufficient income to buy the insurance.
} 
First, however, it is useful to consider briefly an equity argument for compensation.

\section{On the Distributional Effects of Compensation}

Assume that whenever the government exercises its right of eminent domam, it maximizes social welfare. Whenever the government regulates land use or physically takes a parcel of land, it is exercising its "public property rights," while at the same time redefining the rights of private property owners. Thus, changes in rights or redistributions are beneficial to some members of society and correspondingly detrimental to others. Compensation, however, can make it possible for the "winners" to compensate the "losers," so that no one is made worse off by regulatory pohicy. Although such compensation will leave all members of society better off, it is rarely found in practice.

For example, consider a parcel of land withm a residential neighborhood containing 100 homes. On this parcel of land is a junkyard. Because of its convenient location within the city, the land is worth $\$ 200,000$. However, offensive odors emanate from the site and the cost of eliminating these odors is high. The residents of the neighborhood petition the city to zone the land on which the junkyard sits for residential use only. If this zoning change is enacted, the value of each of the 100 homes in the neighborhood will increase by $\$ 10,000$, and the value of the junkyard site will fall by $\$ 100,000$.

Should the city enact the proposed zoning legislation? Any reasonable cost-benefit calculation suggests that the land should be zoned for residential use. Property values withm the neighborhood, the junkyard site excepted, will rise by a total of $\$ 1,000,000$. The value of the junkyard site will fall by $\$ 100,000$, only one-tenth of the gam. It is reasonable to suppose that the purchasers of the products sold by the junkyard, attracted to it by its convenient location, will not lose much because they pay for its convenient location through higher prices. If lower priced, less convenient alternatives are available, purchasers will save money at the cost of convenience. But this is generally not a great economic loss. Thus, simce consumers are unaffected and net property values increase, the benefits greatly exceed the costs.

In this setting, compensation will not affect the outcome of the cost-benefit calculation. Compensation will, however, alter the distribution of the benefits. Of the $\$ 1,000,000 \mathrm{~m}$ neighborhood benefits generated by the new regulation, $\$ 100,000$ is not a gain, but rather a transfer of wealth from the owner of the junkyard to the neighborhood homeowners. Any redistribution of property rights, which may result from a physical taking of land or from a regulation that changes the manner im which the land is used, may create a "social surplus"-a net 
social benefit. But it also redistributes income. If total or partial compensation is paid, it becomes possible to separate the social benefits from the income distribution effects of the regulation.

Divorcing social benefits from income redistribution through government coinpensation has two beneficial effects. First, it reduces the potential unfairness inherent in regulation without compensation. The payment of compensation is not a windfall to the junkyard site owner, but a redistribution of incoine from those gaining by the regulation to those who have lost by it. Fairness will sometimes require such redistribution.

Second, government compensation solves the practical problems associated with individually negotiated or market-based compensation. In the example above, if coinpensation were required for any change in land use mandated by the city, every resident of the city, mcluding the junkyard site owner would be in favor of (or, in the case of the site owner, not opposed to) the zoning change. ${ }^{54}$

However, the practical problems associated with such an individually negotiated or market solution to the compensation question are substantial. Any new homeowner gains only $\$ 10,000$ from the proposed change, but if he were to purchase the junkyard in order to control its use he would lose $\$ 100,000$ (a $\$ 200,000$ purchase price with $\$ 100,000$ resale value as residential property). The market can only achieve the required transaction if ten or more property owners band together and collectively purchase the junkyard site. However, if $N$ homeowners were to band together, they would each gaim $\$ 10,000$ $\$ 100,000 / N$. But the remaining homeowners would gain $\$ 10,000$, and bear no loss from the purchase of the junkyard. This is an example of the classic "free-rider" problem, the potential for which makes any coalition of homeowners unstable.

However, compensation paid by government solves the "freerider" problem. Such compensation would be paid by the city froin property tax revenues. These payments are not a tax on the government, but a redistribution of income from all property taxpayers to those harmed by various governmental acts. Having the government enforce zoning regulation solves the free-rider problem, because everyone must bear the cost. Everyone pays taxes, and so, in this simple example, there are no free riders.

Thus, the payment of compensation can promote a distribution of the gams from a socially beneficial governmental act so that there are no losers. In such an analysis, the compensation scheme plays no role

54. In theory, if it is impossible to arrange compensation so that everyone would vote for the change in the zoning law, the proposal could not have been socially beneficial. The sum of the costs would exceed the sum of the benefits. 
in the improveinent in social welfare. Rather, it only addresses a fair distribution of benefits. In the next Part, we go further and argue that the payment of compensation, apart from distributional concerns, can itself increase social welfare.

\section{III \\ The Market Failure Approach to the TAKINGS QUESTION}

If economic efficiency is the desired goal, those governmental acts that constitute a taking (and thus require compensation) can be inore easily identified. If all markets are competitive and no externahities are present, then economic efficiency will be achieved. ${ }^{55}$ However, due to the presence of risk, there is good reason to believe that the land market is not efficient. This Part suggests that market failure occurs because the private market is not able to provide imsurance in the event of a physical invasion of land or a regulatory change that reduces land values. Simce the private market has failed, only a government-provided remedy can improve social welfare. However, direct government insurance is raised and rejected as a serious alternative to private insurance. This naturally suggests the possibility that compensation for regulatory loss can be viewed as a viable alternative to private insurance. However, such compensation-based msurance is limited by administrative costs. These costs mclude the cost of determining the level of compensation and the cost of writing and delivering checks. Given these costs and attitudes towards risk, the efficiency approach will reveal where the compensation line must be drawn.

The efficiency approach to alternative compensation rules is an instrumentahist analysis. ${ }^{56}$ Under the mstrumental approach, the goal of minimizing the costs (or maximizing benefits) associated with a particular policy determines the worth of a given policy. In the takings context, a desirable compensation rule minimizes three costs: the cost of the disutility associated with the risk that private landowners must

55. This is a restatement of the now classic theorem that presents a set of necessary and sufficient conditions under which a set of competitive markets will be associated with an efficicnt equilibrium. See generally G. Debreu, Theory of VAlue (1959). For more recent discussion of the efficiency issue, see, e.g., K. ARrow \& F. HaHn, General Competitive ANAlysis (1971); Radner, Competitive Equilibrium Under Uncertainty, 36 ECONOMETRICA 31 (1968).

56. For a discussion of the instrumentalist approach, see Shavell, Strict Liability $v$. Negligence, 9 J. Legal Stud. 1 (1980). See also G. Calabresi, The Costs of Accidents: A LEGAL AND ECONOMIC ANALYSIS (1970). Our instrumentahist approach differs from Professor Calabresi's in that he does not explicitly consider the minimization of risk. In the above study of accidents, Calabresi describes three subgoals associated with cost reduction. They include the reduction of the number and severity of accidents, the reduction of the societal costs of accidents, and the reduction of the admimistrative cost of accidents. None of these goals explicitly considers the reduction of the risk that might be facing risk-averse accident injurers or victims. 
bear; the administrative costs of compensation; and the cost to society if the government makes erroneous regulatory decisions that are influenced by the nature of the compensation available.

To develop the argument more formally, it is useful to imagine three sets of econonic actors whose decisions are relevant to the takings question. First, a governmental body is responsible for making the regulatory policy decision. ${ }^{57}$ Second, private landowners are affected by this decision. ${ }^{58}$ Finally, a governmental body is responsible for determining how and when compensation ought to be paid. In our theory, this governmental unit might be designated by statute or it might be a court. In American law, the first and the third actors, although often different groups of individuals, are usually parts of the same governmental unit. ${ }^{59}$ We distinguish the two, however, for analytical purposes and we do not concern ourselves with the nature of the body determining compensation.

For example, consider a situation in which a local zoning board is responsible for changing the zoning of a parcel of land froin commercial to exclusively residential. Unless otherwise stated, we assunne that the zoning decision itself increases social welfare. Despite an increase in social welfare, a zoning decision may negatively affect a particular landowner. For example, a restriction on the use of a particular parcel of land may lower its value. ${ }^{60}$ Private landowners, therefore, inay be substantially affected by the zoning board's pohicy decision. ${ }^{61}$ However, under our expansive view of the role of compensation, the local municipal government (for example, the city council) inay be granted the power to decide whether compensation is to be paid for the lost land value in such a case. Thus, the individuals making the compensation decision need not be the saine individuals who serve on the zoning board, and the two groups are best kept distinct for analytical

57. This includes the governmental body responsible for constructing a public project, such as a highway commission, or a governmental unit, such as a zoning board, responsible for amending the jurisdiction's regulations.

58. Of course, regulation of a particular parcel of land may bestow an external benefit or impose an external harm on the owner of a neighboring parcel. However, for the sake of simplicity, we leave the neighbor out of the discussion.

59. The government unit which determmes compensation payments may or may not be the same group that is responsible for the project decision. For example, the highway commission might have the authority to compensate for the land that it takes, but one can also imagme a separate body responsible solely for the compensation decision. On the other hand, the two groups are identical when the formal exercise of emment domam is involved.

60. See Stull, Community Environment, Zoning, and the Market Value of Single-Family Homes, 18 J. L. \& ECON. 535 (1975).

61. The economic impact of a zoning decision may be reflected not only im land values, but also in the wage rates offered by zoned businesses. See Rubimfeld, Suburban Employment and Zoning: A General Equilibrium Analysis, 18 J. Reglonal SCI. 33 (1978). 
purposes. $^{62}$

\section{A. Risk and Insurance in the Land Market}

When an individual investor is deciding whether to buy and develop a parcel of land, she is likely to take into account not only the risk associated with the possible actions of other individual investors, but also the risk associated with the possible effects of government action. ${ }^{63}$ Are private investors harmed by the uncertainty associated with future governmental actions?

Two things may happen after an investor buys a piece of land. Either the government will exercise its regulatory power, causing some diminution (or appreciation) in the value of the parcel, or it will not. This exercise of regulatory power changes land values and therefore exposes the investor to risk. Although this risk can be initigated by the payment of compensation, such compensation cannot be provided without cost; a broadly based compensation prograin requires an equivalent increase in government revenues, which results in an increased tax hability. Since the following economic treatınent of risk inay be unfamiliar to some readers, we begin with a brief exposition of the theory of risk bearing.

When confronted with a bet or gamble, it is natural to compute its average or expected value. If, for example, a bettor were offered a bet of a dollar on the flip of a fair coin-for example, receiving a dollar im the event of "heads" and paying a dollar in the event of "tails"- the average or expected winnings would be zero dollars. The bettor might say that this opportunity presents no change in his welfare because, on average, the bet creates no change in his wealth. For a bet of a dollar, this may be right, but if so, it is correct not simply because the expected value of the bet is zero dollars, but because there is little difference between the two possible outcomes of the bet: the bettor's initial wealth plus one dollar, and his initial wealth minus one dollar.

Now suppose that the anjount of money to be exchanged is not a dollar, but the bettor's entire wealth. This bet represents a substantial

62. If the compensation rule were to affect the decision to regulate, all of the costs and benefits associated with the regulation would themselves come into the analysis. Thus, for example, one might differentiate between compensation rules that are likely to discourage beneficial activities on the part of the government, and rules that may discourage activities that are deemed to be socially uudesirable.

63. Recall that it is assumed mitially that the goverument agency that zones or takes land for public projects is acting in a manner that is welfare enhancing and somehow determined to be socially appropriate. Also, the goverument is assumed to be making its decisions without regard to whether the costs associated with the decision appear on its budget or not. In part, this involves the assumption that it is both politically and economically costless to raise tax revenues to pay for compensation. 
change in the bettor's welfare, even though its expected value is again zero dollars. The bettor now might argue that the bet's expected value is largely irrelevant to his decision. The coin will be flipped only once, and as a result of the flip the bettor will either double his wealth or become a pauper. Thus, although expected value provides information about the outcome of inany repetitions of a gainble, this information is not very important if the gamble occurs only once and unay have drastic consequences.

In other words, the bettor will evaluate the latter bet by looking at the two outcomes of the bet-zero wealth and double wealth-and at the probabilities of each outcome-one-half. If he places a greater value on the possibility of a win than on the possibility of a loss, he will accept the bet. If he is risk neutral and cares only about the expected return on the bet, he will be indifferent. ${ }^{64}$ If he values the possibility of a loss more than the possibility of a win, he will reject the bet. In the latter case, which most of us would regard as typical, the investor is said to be risk averse. If a bettor is risk averse he would have to be paid a certain amount of inoney to accept the bet or, equivalently, he would pay to avoid the bet. This amount of inoney is called the risk premium, ${ }^{65}$ and it provides a dollar measure of the cost to the bettor of the risk created by the bet.

The following two related examples illustrate the relevance of riskaverse behavior to the taking question, and the interrelationship between the expected value of a given gainble and the possible outcoines of that gamble.

Example 1(a)

An investor owns a parcel of property that, if left untouched, is worth $\$ 500,000$. However, the government is considering the possibility of zoning the parcel for use as a park. ${ }^{66}$ The probability of a rezoning is 0.01 . Assuming that no compensation will be paid, the investor faces a gamble. With probability 0.99 his land is worth $\$ 500,000$ and with probability 0.01 his land is worth nothing. Thus, the expected value of the gamble is $\$ 495,000(0.99 \times \$ 500,000+0.01 \times \$ 0)$.

However, hike the coin flip for the bettor's entire wealth, the possible outcomes of the gamble are extreme and the expectcd value inay not provide an accurate indication of the value of the gamble. Rather,

64. Compare, for example, one investment which guarantees a return of $\$ 100$ with certainty, and a second which will give a return of $\$ 50$ with probabihty 0.5 and a return of $\$ 150$ with probability 0.5 . Because the two have identical expected returns, the risk-neutral investor will treat them as equivalent. With risk neutrality, there is no cost, psychic or otherwise, associated with the risk.

65. A formal definition of risk premium is presented in the Appendix.

66. The park use is assumed to be socially desirable in that the benefits are greater than the costs. 
the true economic value of the land to the investor is the expected value of the site, $\$ 495,000$, less the risk premium he associates with the gamble. Thus, the inore risk averse the investor is, the less the land is worth to him. ${ }^{67}$

Now consider a sliglit variation of the above exainple. Example 1(b)

The investor has the $\$ 500,000$ parcel of land, on which he has placed a stockyard. The city council, responding to pressures froin the residents of the adjacent residential neighborhood, is considering zoning the land for residential use only, and the probability of a rezoning is 0.1 .

If the ineasure passes, the investor will build a housing developinent on his site. However, the value of using the land for residential purposes is only $\$ 450,000$. Although the expected value of the gamble he faces is again $\$ 495,000(0.9 \times \$ 500,000+0.1 \times \$ 450,000)$, the two outcomes are not as extreme as in the prior example. As a result, the risk premium is likely to be less. ${ }^{68}$

A second example illustrates a frequently held fallacy about the inanner in which inarkets account for risk.

\section{Example 2}

Suppose that an investor owns a parcel of land which, if left untouched, is worth $\$ 500,000$. Another investor is contemplating purchasing the land. As things now stand, the second investor is willing to pay $\$ 500,000$ for the parcel. Both investors are concerned about the possibility of a new government regulation that would lower the value of the property to $\$ 200,000$. However, they consider such a possibility unlikely, with a probability substantially less than 0.1 . The $\$ 500,000$ value reflects the fact that the owner of the property, as well as prospective buyers, are risk averse and perceive only a small risk associated witl ownership of the property.

Suppose, however, that it suddenly becomes known that the regulation has a 0.5 probability of passage. Then, the expected value of the parcel is $\$ 350,000(0.5 \times \$ 500,000+0.5 \times \$ 200,000)$. If the second mvestor is risk neutral-indifferent to risk bearing-he will now be willing to pay only $\$ 350,000$ for the land. However, if he is risk averse, his risk premiuun will measure the cost of bearing the risk imposed by the possibility of governmental action. With a risk premium of $\$ 25,000$, the second investor will be willing to pay only $\$ 325,000$ for the parcel. $\$ 50,000$.

67. For example, a very risk-averse individual might have a risk premium as high as

68. Technically, the statistical variance of the second gamble-a possible measure of risk-is smaller than that of the first gamble. 
If the purchase price is $\$ 325,000$, it should be clear that the second mvestor is not hurt by the risk, because the market price of the land has fallen not only by the loss in expected value, but also by the cost of the risk imposed by the government. In other words, the cost of the gamble imposed by the government has been "capitahized" into the price of the land.

In Example 2, the second investor does not bear the cost of the possible regulation. It is fallacious to argue, however, that because of capitalization there is no cost associated with the risk generated by the government's consideration of land use regulation. Rather, the first investor must bear the cost. His land, which was formerly worth $\$ 500,000$, is now worth only $\$ 325,000$. In short, the first investor paid $\$ 500,000$ for the parcel on the premise that there was little risk involved-the probability of a regulation was substantially less than 0.1 . However, an accurate accounting of the situation now shows us that the individual faced substantial risk - the risk that the known likelihood of the passage of the regulation would mcrease froin 0.1 to 0.5 . Thus, without the prospect of compensation, risk is borne by the first investor and by other investors in similar situations. Moreover, the risk is not simply that the land will be regulated and the individual will be directly harmed, but that public knowledge concerning the prospects of a regulation will change. When public knowledge changes, the value of the parcel correspondingly changes. Thus, the investor is still harmed, albeit less directly.

Individuals do, of course, vary in the extent to which they are averse to risk. It is likely that individuals not averse to risk will purchase the most risky properties. However, risk-averse individuals will also purchase risky properties and avoidable economic costs will arise whenever they do so. Economic costs are incurred not only because risk is borne by the individual, but also because land use decisions can be distortcd by risk.

The following example illustrates how risk and risk aversion bear on the use to which land is put.

\section{Example 3}

Investor $A$ has for sale a parcel of land potentially subject to government regulation that will render the land essentially valueless. Investor $B$ contemplates a project for the site that will generate $\$ 500,000$ in economic profits. Investor $C$ contemplates a project for the site which would generate $\$ 470,000$. If there were no possibility of government regulation, $B$ would outbid $C$ and the land would be used for $B$ 's project. This is the most efficient outcome.

Suppose, however, that there is a 0.1 probability that the proposed regulation will actually be enacted, and that if this occurs, no compen- 
sation will be paid. In this case, $B$ 's project has an expected value of $\$ 450,000(0.9 \times \$ 500,000+0.1 \times \$ 0)$, and $C$ 's project has an expected value of only $\$ 423,000(0.9 \times \$ 470,000+0.1 \times \$ 0)$. But suppose that $C$ 's risk premium for the gamble is $\$ 2,000$, while $B$ 's is $\$ 32,000$. $B$ would bid at most $\$ 418,000$ for the land, whereas $C$ would bid $\$ 421,000$. The land would be used for $C$ 's project, even though $B$ 's project has a higher expected return. If expected profits are a good measure of the expected social value of the two projects, as is frequently the case, and individuals vary in their aversion to risk, the possibility of an uncompensated government taking allows land to be used in an inefficient inanner. ${ }^{69}$.

In Example 3, we see that not only is a socially imefficient project undertaken, but also that the lack of compensation provides an implicit subsidy to the less risk-averse investor. This phenomenon is quite general. The absence of compensation imposes costs on risk-averse investors in proportion to their degree of risk aversion. Equivalently, it provides a subsidy to less risk-averse investors by imposing higher costs on their more risk-averse competitors.

Who are the beneficiaries of this subsidy? While a homeowner may have to bear all of the risk imposed by the possibility of governinent action, larger busmess organizations can eliminate risk in two ways. First, all of the investors in a large organization share the risk, so each investor bears only a small part of the risk of a taking. Second, the organization can invest in other projects with returns that are not highly correlated with the return on the property subject to a potential taking. This diversification will substantially eliminate risk. ${ }^{70}$ Such diversification can be achieved through investment im projects not involving land use, or in parcels of land not subject to the same risks of land use regulation.

The inefficiency that arises when risk-averse imdividuals bear risk

69. In Example 3, two distinct circumstances can arise from the possibility of government intervention. In one situation, the government confiscates the land and does not pay compensation, so that both individual investors lose. In the other situation, the government does not confiscate the land, and $B$ 's and $C$ 's projerts generate profits of $\$ 500,000$ and $\$ 470,000$, respectively. The externakty causing the inarket failure in this example is that an investment decision in one circumstance commits the investor to an investment decision in another circuinstance. We inight think of investments in each situation as different goods. A purchase of one good by an investor commits him to the purchase of the other good. For efficiency to be achieved, individuals must be allowed to make unconstramed choices. As matters now stand, however, these investment decisions cannot be unbundled, and so the wrong project is undertaken. This kind of market failure is pervasive, and is therefore distinguished with its own name. Markets exhibiting the kind of externality just described are said to be incomplete, because there are no markets for the goods that investors would like to trade.

70. The potential gains from this type of diversification, which will not be explored further here, form the basis of modern theories of portfoho management. See generally E. FAMA \& M. Miller, The Theory of FinANCE (1972). 
can be rectified by insurance. ${ }^{71}$ Insurance does not eliminate risk, but it does provide a ineans of redistributing risk among investors. ${ }^{72}$ For example, in the case of government insurance, risk is shifted froin landowners to the government. Thus, to the extent that government is thought to be less risk averse than private investors, there will be increased efficiency.

The following exainple illustrates how insurance redistributes risk. Example 4

Consider a hoineowner whose house and contents are worth $\$ 100,000$. A fire that will destroy everything has a 0.01 probability of occurring. Without insurance the expected value of the hoineowner's gamble is $\$ 99,000$. This position is quite risky since the possibility of total loss remains.

Suppose, however, that an insurance coinpany offers a policy for $\$ 1,200$ which will pay the entire $\$ 100,000$ loss if a fire occurs. If there is

71. The market failure of the last example could be remedied if it were possible to trade separately for investment possibilities in each circumstance. Insurance is the inost common institution which achieves this goal. The sale of an insurance contract obligates the vendor to provide a specified amount of money to the purchaser in the event that a specific circumstance occurs. For example, homeowner's insurance obligates the vendor to pay the purchaser a fixed amount of money if the purchaser's home and its contents are destroyed. Auto insurance requires the vendor to meet certain legal obligations of the purchaser in the event that certain kinds of auto accidents occur. Thus, insurance markets provide a means of unbundling decisions about consumption or investment in various situations. See supra note 69.

72. Stock markets play the same role for investors that markets for imsurance policies play for homeowners. For example, consider a situation involving two investors. Investor $A$ has $\$ 100,000 \mathrm{in}$ cash, and is currently involved in a project that pays $\$ 500,000$ with probability 0.8 and pays $\$ 0$ with probability 0.2 . Thus, his net wealth is described by the gamble that pays off $\$ 600,000$ with probability 0.8 , and $\$ 100,000$ with probability 0.2 . Investor $A$ is risk averse, and although the expected value of this net investment position is $\$ 500,000$, he associates with his gamble a risk premium of $\$ 20,000$. Thus, his position is worth only $\$ 480,000$ to him.

Investor $B$ has $\$ 500,000$ in cash and no risky investments. Suppose he offered $\$ 380,000$ to $A$ for his participation in the risky imvestment project. $A$ would sell (im fact, he would just be indifferent between selling and holding), and would be left with $\$ 480,000 . B$ would now be in a risky position. His wealth would be $\$ 620,000$ with probability 0.8 and $\$ 120,000$ with probability 0.2 . The expected value of $B$ 's risky position is $\$ 520,000$. Suppose that the risk premium $B$ associates with this gamble is $\$ 15,000$. Then he will view his ex post purchase position as worth $\$ 505,000$, while his ex ante purchase position was worth only $\$ 500,000$. Thus, he will make a profit of $\$ 5,000$ by entering into the transaction. The cost of the risk associated witl participation in the risky investment project is $\$ 20,000$ when the participation is by $A$, and $\$ 15,000$ when by $B$. The transfer of risk from $A$ to $B$ has resulted in a total savings of $\$ 5,000$ in the cost of bearing risk, and this is $B$ 's profit. If $B$ 's risk premium for his post-purchase gamble was $\$ 25,000$, then he would not buy $A^{\prime}$ 's participation. If he did, he would lose money, the exact amount being the increased cost of risk bearing that would result from his participation rather than $A$ 's.

It is generally accurate to assume that the cost of risk bearing increases with the size of the gamble, and so in this situation a more likely outcome is that $B$ will purchase some part of $A$ 's participation in the project. In this example, wheu $B$ purchases a share of $A$ 's participation in the investment project, he is effectively insuring $A$ for part of the risk to which $A$ is exposed. In this case, the efficiency of the market for shares in the investment project guarantees that the risk of the project will be distributed among investors in a cost-minimizing manner. 
no fire, the homeowner will have $\$ 100,000$ worth of property less the $\$ 1,200$ paid for imsurance, for a total of $\$ 98,800$. If the fire occurs, the homeowner will lose his house and possessions, but he will receive $\$ 100,000$ from the imsurance company. But since he will have paid out $\$ 1,200 \mathrm{~m}$ premiums, his net worth will still be $\$ 98,800$. In short, the purchase of complete imsurance coverage for $\$ 1,200$ guarantees him, fire or not, a net worth of $\$ 98,800$. Simce the expected value of the gamble is $\$ 99,000$, the homeowner will purchase the insurance policy only if his risk premium is greater than $\$ 200$. However, if he does purchase the insurance policy, the risk does not disappear. Instead, the insurance company bears the risk.

The possibility of government condemnation or regulation of land similarly imposes risk on imvestors in the land market, and if the mvestors are risk averse, this has a cost. This cost can, im principle, be measured by the risk premiums landowners associate with the gamble created by the possibility of government action. The presence of "regulatory" risk can distort land use decisions, and the effects of this distortion will often impose costs on others who are not directly imvolved im the land market but whose activities are complementary to the activities directly mvolving land. This cost of risk can be diminished by insurance or other risk-sharing agreenents, which can arise from two sources: the government and private markets. ${ }^{73}$ We shall first consider why compensation, provided ex post, acts as a rudimentary form of imsurance, and as such, can imcrease social welfare.

\section{B. Compensation as Insurance}

Consider the following simple example.

\section{Example 5}

An individual homeowner is contemplating the purchase of a parcel of land and a house, valued at $\$ 100,000$. At the time of purchase the individual is aware that there is a 0.5 probability that the government will choose to rezone neighboring land to permit dumping of toxic chemicals. This would create noxious odors and lower the value of the house to $\$ 50,000 .^{74}$

Assuming that the individual homeowner correctly perceives the risks involved in the regulatory process, we can calculate the expected return on the property with or witliout compensation after the rezon-

73. If private markets can efficiently provide insurance, government intervention will not be needed. However, we will argue moinentarily that private markets for takings insurance are likely to be imefficient. See infra Section C.

74. This is an unusual example for consideration as a taking, since the individual use of land is not being restricted and there is no physical invasion. However, it is relevant for our theory since investor risk is involved. 
ing. With compensation, the property would be worth $\$ 100,000$ to the mvestor, whether or not the regulation is enacted. On the other hand, without compensation, the expected return on the land would be $\$ 75,000(\$ 100,000 \times 0.5+\$ 50,000 \times 0.5)$.

However, the expected returns will be identical if the individual buys an insurance pohicy which provides coinpensation in the event of regulatory harm, and the premium is equal to the expected level of coinpensation. In other words, the individual landowner would pay $\$ 25,000$ for the right to insurance compensation $(\$ 25,000=0.5 \times$ $\$ 50,000+0.5 \times \$ 0)$. Thus, a risk-neutral investor would be indifferent between purchasing the land for $\$ 75,000$ without insurance, or paying $\$ 100,000$ for the land with insurance, $\$ 25,000$ of which pays for the right to receive compensation.

Under the assumption of risk neutrality, the investor would be indifferent between the expected return of $\$ 75,000$ on this parcel of land, and a certain return of $\$ 75,000$ on an alternative parcel of land. If the individual were risk averse, however, she would need to be compensated-that is, paid a premium-to be induced to purchase the risky asset. $^{75}$ If insurance were not available, and if there were no individuals in the market who were risk neutral or less risk averse, the investor would presuunably negotiate a lower purchase price for the risky investinent. Thus, the sale price of the land subject to government regulation, if all investors were risk averse, might be $\$ 65,000$ rather than $\$ 75,000$.

Are individuals who invest in land risk averse? Part of the answer hes in the general desire of investors to avoid risk. There is substantial evidence that individuals are risk averse im many of their day-to-day activities. We notice this because people buy insurance to protect themselves against certain possible outcomes, although they generally insure against devastating losses as opposed to sinall losses. The fact that individuals often diversify their investments to the extent that they have sufficient wealth to do so also provides evidence of risk aversion.

Land markets involve substantial risks because of the inagnitude of the dollar investment. Other investments, usually on a smaller scale, offer the opportunity to diversify risk, but housing often does not. For example, when a homeowner purchases a parcel of land, the investinent in the land and structure often represents a substantial portion of that individual's net worth. When purchasing an asset that makes up

75. Risk-averse individuals will, of course, want to insure themselves against risk to eliminate risk altogether. This can be achieved to soine degree because the bankruptcy laws limit one's liability in certain situations, and because one can spread risk by buying a number of parcels each witl a different type of risk. However, neither the bankruptcy laws nor large-scale investment is necessarily capable of elimimating all of the risk that investors face. 
such a large portion of one's wealth, one is likely to be very wary of undertaking risk. ${ }^{76}$ Individuals would presumably be willing to pay something to insure against the prospect of a factory moving nearby and imposing substantial externahities. Thus, even though the probability of government action reducing the value of land may be relatively low, the potential consequences in terms of the expected losses and the effect on landowners can be very large.

As a consequence of their risk aversion, such imvestors would consider the possibility of buying insurance sufficient to cover themselves against future losses. In fact, if the insurance available privately were actuarially fair, with a premium equal to the expected loss and without administrative costs or add-ons, investors would fully insure against risk. For example, if there is a fifty-fifty chance that a zoning change would lower the value of a parcel of land by $\$ 50,000$, as in Example 5, then actuarially fair insurance would cost $\$ 25,000$. The availabihity of this actuarially fair insurance allows the individual to turn a risky investment into a certain one. Thus, rather than paying $\$ 75,000$ for the parcel with the risk of earning either $\$ 100,000$ or $\$ 50,000$ depending upon governmental action, the individual pays $\$ 75,000$ for the parcel as before, but purchases an insurance contract for $\$ 25,000$. With the insurance contract, the individual has paid $\$ 100,000$ independent of any government action. If no taking occurs the market value of the land is $\$ 100,000$; if the zoning regulation is changed, the value falls to $\$ 50,000$, and the insurance payment of $\$ 50,000$ compensates for the loss. Thus, with full information and competitive markets, including the market for insurance, the allocation of resources will be an efficient one in which risk-averse individuals purchase full insurance against all uncertainties.

Of course, if individuals are sufficiently risk averse, they will want to purchase insurance agamst governmental action even if the insurance is not actuarially fair, that is, even if there are administrative costs involved. For example, the individual might pay $\$ 30,000$ for an insurance contract that would fully compensate hiln im the event of governinental action in the above example. In this case the purchase price of the land would be $\$ 100,000, \$ 30,000$ of which would reflect the insurance premium.

\section{Private Insurance or Market Failure?}

This analysis suggests that an efficient outcome will be attained only if a competitive insurance market exists, or if there are some risk-

76. Specifically, individuals with greater "absolute risk aversion" will pay more to avoid larger risks than to avoid smaller risks. See infra text accompanying notes 97-99. 
neutral individuals who value the land as highly as those who are riskaverse. Unfortunately, there are often no inarkets in which individuals can insure theinselves against the risk of government action. To see why this is so we inust distinguish the risk of government action froin the case in which private investors are concerned about the actions of other private individuals in the land market.

When purchasing a parcel of land from a willing seller, the purchaser can write provisions into the contract that provide for either damages or compensation if certain future events occur. Thus, in the private market, when a small number of parties are involved, mdividuals can negotiate an appropriate insurance pohicy. The extent to which insurance is provided in any land contract will depend upon the extent to which each of the contracting parties is risk averse. Of course, it is possible that such clauses will arise because one party prefers risk and the other party is risk neutral, in which case compensation is not necessary, but the risk-preference case is unlikely. ${ }^{77}$

While contracts that provide some kind of insurance occur frequently in private land inarkets, arrangeinents that provide insurance against the actions of the government are rare. ${ }^{78}$ When purchasing land, why do individuals not write contracts which require compensation if the land is physically taken or severely regulated? Or, why do private imsurance companies not sell takings insurance? The answer hes in the fact that inarkets for insurance against such governmental actions are not perfect.

The first source of imperfection in the insurance inarket is called moral hazard. Moral hazard occurs when the party to be insured can affect the probability or the magnitude of the event that triggers payment. Thus, if a private insurance coinpany were providing a policy to protect against future governmental events, it would be concerned about the possibility that the individual landowner might be in a position to affect the decision of the zoning board, and thus the probability that the government action would occur.

Consider, for example, the owner of a warehouse worth $\$ 100,000$. If the owner runs a fire prevention prograin at a cost of $\$ 50$, the probability of a fire is 0.005 . Should he choose not to have this program, the probability of a fire is 0.01 . Now consider the dilemnna fac-

77. If both parties are risk averse, the buyer will be unable to insure fully, and will bear some of the risk himself. This prospect can be avoided, however, if he can purchase insurance from an organized insurance market, even if all of the participants in the market are individually risk averse. In the insurance market, any risk is divided among all of the participants, so that each bears only a small portion of the total risk.

78. Occasionally in contracts involving apartment buildings, exphicit provisions will be included which specify who is liable when and if there is a formal exercise of the eminent dounain power. 
ing the coinpetitive, risk-neutral insurance coinpany. If the fire prevention prograin were in place, the coinpany could insure the warehouse for a preiniuin equal to the expected loss, which is $\$ 500$. However, once the insurance policy is purchased, the owner no longer has an incentive to run the prograin. Thus, the only insurance policy that can be sold in this market is a policy costing $\$ 1000$, which assuines that no program is being run. There is, therefore, a social cost of $\$ 450$, which is borne by the warehouse owner who cannot convince the insurance company that he will run the program. The problem may be solved if the insurance company inomitors its policyholders, but this is a costly activity.

Similarly, private investors in the land market who have insured against regulatory changes would have less incentive to participate in the political process that determines the zoning change if insurance were available. They would be less likely to oppose vigorously those regulations that lower property values. In the worst case, investors who believe that insurance payments will overcompensate them might lobby for the regulation or even bribe public officials. Since individuals are likely to have inore information about their own ability to affect the regulation of land than would an insurance company, and because of the inoral hazard issue, private insurance companies find it difficult to choose an appropriate premium at which to sell insurance. If the premium were sufficiently high to cover the imsurance companies agamst the risk of inoral hazard, nost private individuals would not find it desirable to buy the insurance. Of course, large investors or landowners can avoid this problem by self-imsuring, or spreading the risk among alternative investments.

A portion of the inoral hazard problem could be eliminated if coinsurance were provided. Under a system of coinsurance, the insurer agrees to compensate the policyholder for only a percentage of the loss. As a result, the individual faces soine residual risk even when an insurance contract has been purchased. The risk is substantially reduced, but nay still be sufficient to discourage the individual from acting in a inamier which would alter the probability and the magnitude of the harm.

Such a coinsurance systein effectively exists under our current property tax systein, because property losses result in lower tax liabilities. A property tax reduces, but does not fully eliminate, the gains and the losses that would occur in a system without property taxation. If the property tax were changed to a land tax, in which all changes in land value were taxed at a one hundred percent rate, then full imsurance would exist. However, with the comsurance system we currently 
have, the possibility of further compensation as an insurance mechanism is worth considering.

A second, related difficulty im the private market for taking insurance is adverse selection. Adverse selection arises because imsurers are not always as accurate as policyholders $\mathrm{m}$ assessing the probabilities of the events they are insuring. ${ }^{79}$ Adverse selection renders the operation of insurance nuarkets problenıatic.

For exaunple, suppose an imsurance company looks at a particular event, such as an auto accident that causes only property damage, for which they would like to offer a policy. They select a target population to whom they wish to market this policy and estimate the frequency of accidents within this group. Unfortunately, many target populations are heterogeneous. Within the group of male drivers under age twentyfive, some have a low likelihood of being im an accident. For others, the probability of being involved in an accident is quite high. ${ }^{80}$

Absent government imterference, the market outcome will always be mefficient. To see this, suppose that the insurance company offered a policy based on a 0.01 estimated probability of property damage. This estimate represents an average for the target population; thus for some potential policy owners, the probability of property damage is less than 0.01 . It is not hard to see that if the probability of harm is substantially less than 0.01 , and the individual is risk averse, it will not pay for him to buy the policy. ${ }^{81}$ The premium, based on an accident probability much higher than the individual's true accident rate, will be too costly. As a result, mdividuals in the target population with accident probabilities sigmificantly less than 0.01 will not buy the policy. On the other hand, mdividuals prone to accidents with a probability greater than 0.01 will clearly opt to buy the insurance.

Now the insurance company stands to lose money. It has assumed that the accident probability of the imsured group is, on the average, 0.01 . However, those imdividuals least likely to have an accident will not buy the policy. Therefore, for those who actually purchase the policy, the average property daniage probability will be higher, say 0.02 . As a result, the insurance company will pay out on these policies much more often than it had anticipated. Moreover, if the insurance company tries to correct this by raising the premiums to take account of the fact that the average frequency of accidents is 0.02 , more people will

79. For example, most auto owners can assess their driving skills much better than the companies insuring them can, despite the experience ratings and other classification schemes that insurance companies employ.

80. For purposes of this analysis, it is assumed that all are equally averse to risk.

81. For complete details, see the Appendix. 
choose not to buy the policy and the true frequency for the insured group will increase again.

The likely outcome in this market is that only the individuals in the target population who are most likely to have accidents will purchase insurance. However, this market outcome is inefficient, because everybody else in the target population would like to purchase some insurance, but it would not be profitable for the insurance company to offer a contract that everyone includimg those least likely to have an accident would be willing to buy ${ }^{82}$

Adverse selection can arise in the context of land inarkets as well. Risk-averse individuals who perceive that they are likely to be negatively affected by a zoning change will purchase insurance. Those who are not risk averse and who do not perceive this likelihood will not buy insurance. However, the insurance coinpany might be unable to distinguish among these purchasers and, therefore, it will be unable to set the appropriate preinium for its policies. For example, assume that two equally risk-averse investors in the land market are considering the purchase of a parcel of land and would like to buy insurance against the risk of a government taking. Assume that the possible loss is $\$ 50,000$ and the individuals perceive the probability of the taking to be 0.4 and 0.6 , respectively. The insurance company perceives the risk to be 0.5 , an average of the private individuals' views. Under these conditions, the insurance coinpany in a competitive market will provide an insurance policy for a premium of $\$ 25,000,{ }^{83}$ which will insure individuals against the possible loss of $\$ 50,000$. This policy will allow the insurance coinpany to break even if an equal number of individuals with each set of expectations chooses to buy insurance.

Now assume in addition that the individual who views the probability of a taking to be 0.6 will purchase insurance, while the individual perceiving the risk to be 0.4 will not. If the government action (accurately perceived) will occur with a probability greater than 0.5 , the msurance company will, on the average, lose money. An appropriate msurance premium can be set only if the insurance coinpany can be assured that its information sources are at least as accurate as those of the individuals. Individuals with more accurate information than the insurance company will be gambling with an advantage-they will insure only if they are substantially risk averse, or when the insurance premium is below the expected payout. As a result the msurance com-

82. In fact, this problem is mitigated by statutes requiring all drivers to insure. Any driver with a low accident probability who chooses to opt out of the insurance market risks a substantial penalty in the event that he is discovered to be without insurance.

83. Actually, this market would still not be efficient, because some individuals would be paying too much for insurance and others too little. 
pany will find it difficult to break even over the long run. ${ }^{84}$

The net result is a "market failure" in the competitive economy. The failure is not that existimg markets are not competitive, but rather that a particular market simply does not exist-the market for insurance against future land price changes resulting from government activity. ${ }^{85}$

\section{Curing Market Failure with Government-Provided Insurance}

This private market failure indicates the beneficial aspects of government-provided insurance against the adverse effects of government actions. Nevertheless, it is crucial to determine whether this benefit is greater than the associated costs. The benefits of government-provided imsurance will be great if such an approach can cure the probleins resulting from "market failure." However, any benefits may be offset by other distortions created by compensation payments.

In fact, the idea of government insurance is not new. The federal government allocates a substantial portion of its budget to items with an insurance component, including social security, agricultural price supports, bank insurance, and flood insurance. ${ }^{86}$ Similarly, state governments provide unemployment insurance. Finally, both federal and state governments allocate dollars towards income maintenance programs, which can be viewed at least im part as insurance mechanisms.

Then why not have the government provide direct insurance, sellmg policies to individuals for protection against loss due to government land use regulation? The answer is implicit in our previous discussion of the prospect of government insuring agamst its own actions. The moral hazard problem that exists in the private market would be exacerbated if the government were a direct seller of insurance. To the extent that the government faces budgetary constramts, the project from which the takings stem might be altered to assure that only uninsurcd properties are taken. In the extreme, this would lead to a world in

84. Of course, these problems can be diminished to the extent that imsurance companies can rely on specialists to develop expertise about local markets. Moreover, insurers may be able to avoid some of the adverse selection and moral hazard problems by offering policies which begin several years in the future. The further in the future that the policy goes into effect, the less likely that moral hazard problems will arise. Individuals with information about the possibility of regulatory change cannot profit from that imformation without substantial time delays, during which the private information is likely to become public.

85. Contrast the success of title imsurance, where landowners are apparently risk averse and willing to insure agamst the possible loss of title, but few moral hazard or adverse selection problems exist because the harm, if any, has already occurred.

86. See Mirrlees, Notes on Welfare Economics, Information and Uncertainty, in M. BALCH, D. MCFADDEN \& S. Wu, EsSAYS ON ECONOMIC BEHAVIOR UNDER UNCERTAINTY (1974); Varian, Redistributive Taxation as Social Insurance, 14 J. PuB. ECON. 49 (1980). Both argue that there is an important insurance component to income redistribution. 
which individuals who do not desire insurance would purchase it nevertheless in order to protect theinselves from government actions. Correspondingly, individuals representing the government agency providing the insurance inight have an mcentive to sell insurance (for an appropriate side payinent) to those likely to be affected by government actions. Of course, these sources of noral hazard arise in other forms of government insurance. Nonetheless, the potential moral hazard problein seems particularly severe where a local government, which is quite likely subject to a wide array of pohtical imfluences and interests, manages a program of direct insurance. ${ }^{87}$

The direct insurance approach poses another difficulty. The cost of determining an appropriate preinium for a low-probability event may be quite high. ${ }^{88}$ Of course, one could attempt to set premiums on a broad experiential basis, simply by looking at the history of regulatory change in the community, or in similar communities. The moral hazard problein inakes such an approach suspect, however, simce past experience may be a poor predictor of future behavior.

Given the inoral hazard problem and the treinendous cost of providing insurance against risks that occur with low frequency, it seems reasonable to consider an alternative, somewhat mdirect inethod of insurance-the payinent of coinpensation after an injury has occurred. If a clearly defined rule that sets compensation independent of the "strategic" behavior of the policyholders can be specified, then the previously described noral hazard problem can be avoided. The limits to this approach depend upon the nature of the political process involved, and are discussed in inore detail in a later section. ${ }^{89}$

87. For a related discussion on the subject of government failure, see infra Part $\mathrm{V}$.

88. Of course, premiums are set for title insurance, but these reflect mostly the cost of the title search, and do not raise the substantial problems associated with moral hazard and adverse selection that arise in the more general case of imsurance against takings.

89. What are the legal limits to government-sponsored insurance? In one case, the government was held liable for the diminution in value caused by the announcement of an intent to condemn, even though the condeınnation was not actually carried out. See Klopping v. City of Whittier, 8 Cal. 3d 39, 500 P.2d 1345, 104 Cal. Rptr. 1 (1972). However, the insurance argument sketched out in the text is even broader than this. Therefore, why not apply the principle of the argument to a whole host of government actions? For exainple, why not compensate prisoners who are found to have been wrongly declared guilty? Or, why not coinpensate those individuals who have been wrongly deprived of welfare benefits? For a discussion of compensation in a broader setting, see Cordes, Goldfarb \& Barth, Compensating When the Government Harms, in R. Zeckhauser \& D. Leebaert, What Role for Government? 295 (1983); Hochman, Rule Change and Transitional Equity, in H. Hochman \& G. PETERson, Redistribution Through Public Choice (1974).

Clearly many of the issues raised here with respect to the land market can be generalized to apply to other government actions. We simply limit our argument arbitrarily to the compensation question, which naturally arises out of the constitutional issue surrounding takings, and we deal only with land. In a similar spirit we choose not to focus our discussion on the question of taxation for unjust enrichment. All of the arguments which suggest a demand for insurance against 
If compensation were paid to landowners after the fact, the problems of direct insurance would be largely eliminated. First, properties would not be classified as "imsured" or "uninsured," removing the possibility that project plans would be altered to take only uninsured properties. Nor would any bribes be exchanged for the imformation that certain landowners are likely to be harmed by government action, smce no msurance would be sold. Finally, the cost of determining the appropriate tax rate to fund the compensation scheme would be substantially less than the cost of determining the appropriate direct imsurance premium, especially given the likely alleviation of the moral hazards involved in direct government msurance.

If compensation is paid as insurance after the fact by the government, the source of the premiums must be considered. It is not possible for the individuals actually harmed to pay premiums directly, smce we cannot evaluate the magnitude of the harm until after the fact. It is equally difficult, however, to charge individual premiums before the fact, in part because of the substantial cost imvolved in the determination of appropriate premiums. The more practical approach is to raise the premium revenue through general property taxation. The administrative costs are obviously quite low, since the property tax system is already in place. However, sonie potentially serious distortions are created when the premiums paid through property taxes do not accurately reflect the premiums that individuals would pay in a private competitive imsurance nıarket.

\section{IV}

\section{MARKET FAilure AND COMPENSATION: Where to DRAW THE LINE?}

As the precedimg analysis indicates, market failure provides a rationale for considermg the payment of compensation not only when

\footnotetext{
the possibility of a loss in land value would apply equally as well if one were to consider the possibility of insuring against the uncertain nature of an expected increase in land value. The avoidance of risk involves the elimination of uncertain outcomes whether they be utility diminishing or utility enhancing.

Of course, the government does partially insure against unjust enrichment. To the extent that assessed valuation of property increases in response to increases in land value, some partial insurance against gains in value is provided. The government simply taxes away a portion of those gains, which can be used to coinpensate for lower taxes on properties that lose value. The substitution of a land value tax with a relatively high tax rate for the property tax would go far toward achieving the insurance goal suggested here. By taxing away gains and reducing taxes when losses are involved, the land tax would cushion the landowner from the effects of most risks. The argument for partial compensation has been pursued by a number of commentators. See Bosselman, The Third Alternative in Zoning Legislation (pt. 2), 17 Zoning Dig. 113 (1965); Hagman, Temporary or Interim Damages Awards in Land Use Control Cases (pt. 1), 4 ZoNing \& PLAN. L. REP. 129, 131 (1981).
} 
land is taken by eminent domain, but also when zoning changes or other governmental regulations affect land values. But this does not mean that coinpensation should be provided in all cases of insurance market failure. There are a number of costs associated with compensation, and we can only conclude that compensation ought to be paid when the benefits outweigh the costs. In this Part we exphcitly consider the kinds of compensation that the government can pay when insurance is not available privately, and we specify the nature of the costs involved with each such governmental compensation plan.

\section{A. Measuring Aversion to Risk}

There is no doubt that government actions have frequent and sometimes substantial effects on land values. There is some doubt, however, about the costs of administering a program which would estimate empirically the magnitude of those effects. At one extreme is a physical taking of a parcel of land. In this case, the current property tax assessinent process would provide a good beginning for the deterinmation of fair market value. ${ }^{90}$ Since comparable sales are often available and assessinent processes can be computerized, the additional adinimistrative cost of msuring an extra parcel of land against such losses would be quite low. The saine general argument would inost likely be true if one were discussing a zoning amendment or variance that had an impact on a specific parcel. Here the costs of verification and analysis should also be relatively small.

At the other extreme, however, the costs of administration would be high if the zoning ainendment has a broad geographical impact. In such a situation, measurement of land price changes would be difficult, in part because of the magnitude of the problem, and in part because it is difficult to "control" for other variables that might change in the process. Of course, the difficulty of measurement inight also increase the probability of administrative or court litigation, which renders administrative costs unacceptably high.

Thus, the compensation payment line depends in part upon the structure of the administrative proceedings and in part upon the likelihood of litigation. In addition, such costs must be weighed against the benefits involved, which will vary with the type of land use and the potential loss in value involved.9

When should governments provide compensation? If efficiency is the sole goal, the answer is the usual one: when the benefits, measured in terms of the dollar value of reduced risk to land investors, outweigh

90. See, e.g., K. CASE, Property TAXation: The Need for Reform (1978).

91. It is not our goal to make a final determination of this issue, but rather to raise these mtriguing but complex issues. 
the administrative costs. Admimistrative costs include the costs of litigation and any economic costs which might arise if the availability of compensation distorts investor behavior. ${ }^{92}$ If there are no administrative costs, the government ought to provide compensation whenever mvestors would have chosen to purchase insurance in the private market. ${ }^{93}$ However, as administrative and economic costs rise, the role for compensation becomes more limited.

By providing such compensation, the government is not replicatimg the private imsurance market. In the private insurance market, individuals would pay a direct imsurance premium for full coverage. In contrast, under a government compensation plan, individuals would not pay a direct premium for government compensation when there is a reduction in land value. Both the compensation and the cost of administration would be paid from general budgetary revenues.

In private markets, the imsurance premium inust cover the administrative cost if the insurer is to break even. The same is true when the government provides insurance. Wlien such costs are present, not all individuals would desire to purchase insurance. Those individuals likely to purchase imsurance agamst the possibility of a taking are: (i) those who generally face a higher loss, and (ii) those who are more risk averse. ${ }^{94}$ These are individuals who would liave purchased private imsurance if it were available. Thus, an appropriate compensation rule requires the relevant public body to compensate only these mdividuals after the fact.

If an individual is averse to risk and actuarially fair insurance can be purchased (from a risk-neutral third party msurer), then it is not difficult to show that the individual will completely msure against the risk. The argument can be seen graphically by referring to Figure 1 . The Curve $O-D$ represents the imdividual's utility function, $u($ ), which calculates the value or utility that the individual attaches to wealth, $w$, as wealth is varied. ${ }^{95}$ Utility mcreases with wealth, but the rate of in-

92. See supra the discussion of moral hazard in Part III.

93. We are assuming that the insurance is priced competitively.

94. Recall the earher discussion in Part IIl in which we suggested that certain individuals may "self-insure" by selecting a broad array of investments. The fact that an individual holds one property that is subject to substantial risk does not preclude the possibility that the individual has sufficient wealth to hold a wide portfolio of risky investments. Thus, there will be cases in which the relative magnitude of loss may provide a poor measure of the extent to which the individual has borne risk. With commercial and industrial property or large residential developments, this argument has substantial force. However, with residential properties and, to a large extent, individual rental properties as well, the housing choice is one that has been made in the distant past, and often under constramts and conditions (such as lack of information) that made the avoidance of risk impossible.

95. The utility function is cardinal in the sense that it translates values of wealth into a numerical index of utility. However, for most purposes it is the ordinal properties of the utility function that are inost important. The extent to which aspects of cardinality are important for the 
FIGURE 1

Risk Averse Individuals Fully INSURE

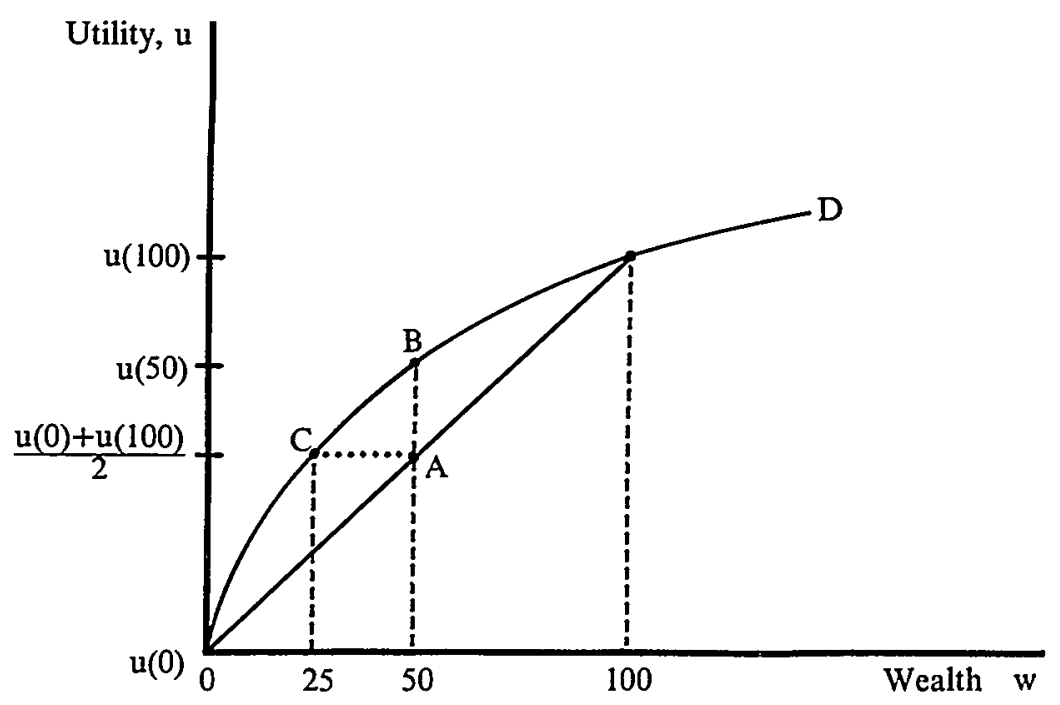

crease itself diminishes. It is this dimmishing marginal utility that is the source of risk aversion.

Consider a gamble or lottery with two outcomes, wealth equal to 0 (for example, a government taking without compensation), and wealth equal to 100 (for example, no taking at all). With no msurance (no compensation) and a fifty-fifty chance of a taking, the level of utility achieved by the mdividual is given by point $A$, which represents an average of the utility achieved with wealth 0 and with wealth 100 . If insurance can be purchased, then the imdividual will pay a premium of 50 to assure himself of a wealth of 50 irrespective of the taking (if it occurs, the msurance payment of 100 mimus the premium of 50 will leave him with a wealth of 50). As a result, the level of utility represented by point $B$ can be assured. Thus, with dimmishmg marginal utility, full insurance clearly benefits the individual.

With actuarially fair msurance (the premium equals the expected payment), individuals will choose to insure fully no matter how risk averse they are. Every dollar that the individual pays to purchase insurance $e x$ ante will be compensated by an equal expected amount of compensation ex post. Thus, although insurance produces no gam in

analysis of risk and uncertainty has been debated in the economics literature for some time. The classic book in the area is J. VON NeumanN \& O. Morgenstern, Theory of Games AND ECONOMIC BEHAVIouR (2d ed. 1947). For a more recent critique and discussion, see K. BorCH, THE ECONOMICS OF UNCERTAINTY ch. 6 (1968). 
terms of expected return, every dollar paid for insurance, including the first dollar, lowers the amount of risk that the individual faces and thus improves her welfare. However, when insurance is actuarially unfair, due to administrative costs, the choice to insure will depend upon the administrative cost and the premium that the individual is willing to pay to avoid risk.

The relationship between the form of the utility function and the risk premium can be seen by reexamining Figure 1. Facing a gamble with equal probabilities of wealth equal to 0 and wealth equal to 100 , the individual achieves a level of utihty associated with point $A$. Now compare point $A$ to point $C$ on the graph. The level of utility achieved at point $A$ is identical to that associated with $C$, since both have the same vertical distance from the origin. However, point $C$ represents the utility attached to the certain outcoine of wealth equal to 25 . The individual is indifferent between a certain wealth of 25 and a gamble with an expected value of 50 , which involves a fifty-fifty chance of attaining a wealth of 0 or a wealth of 100 . Thus, the maximum amount of money that the individual would be willing to give up to insure against the risk (the gamble) would clearly be equal to $25(50-25)$. It is this maximum willingness to pay for insurance which economists describe as the risk premium.

Unfortunately it is difficult to derive many results concerning the theory of insurance using the risk premiun approach. ${ }^{96}$ A more direct method focuses on the degree of risk aversion. Measurement of the degree of risk aversion is a methodologically difficult and controversial subject. In fact, there is no general measure of risk aversion which economists find satisfactory for describing individual attitudes toward risk and imsurance. ${ }^{97}$

Two definitions of risk aversion are commonly utihzed by economists. Absolute risk aversion refers to the individual's willingness to pay to avoid a fixed dollar gamble as the individual's wealth changes. Consider, for example, the choice of a gift of a fixed dollar amount, say $\$ 10$, or a gamble with a 0.5 probability of winning $\$ 25$ (and a 0.5 probability of $\$ 0$ ). With constant absolute risk aversion, the mdividual is equally likely to take such a gainble as her wealth increases. With decreasing absolute risk aversion the individual is inore likely to take the gamble as her wealth increases. Relative risk aversion, on the other hand, refers to an individual's willingness to pay to avoid a gamble of a

96. The literature on the economics of insurance is a large and rapidly growing one. For a recent review, see M. MAChINA, The Economic Theory of Individual Behavior Toward RiSK: TheORY, Evidence AND New DIRECTIONS (Technical Report No. 433, Institute for Mathematical Studies in the Social Sciences, Stanford University 1983).

97. See M. MACHINA, supra note 96 . 
FIGURE 2

\section{Risk Aversion and the COST OF ADMINistration}

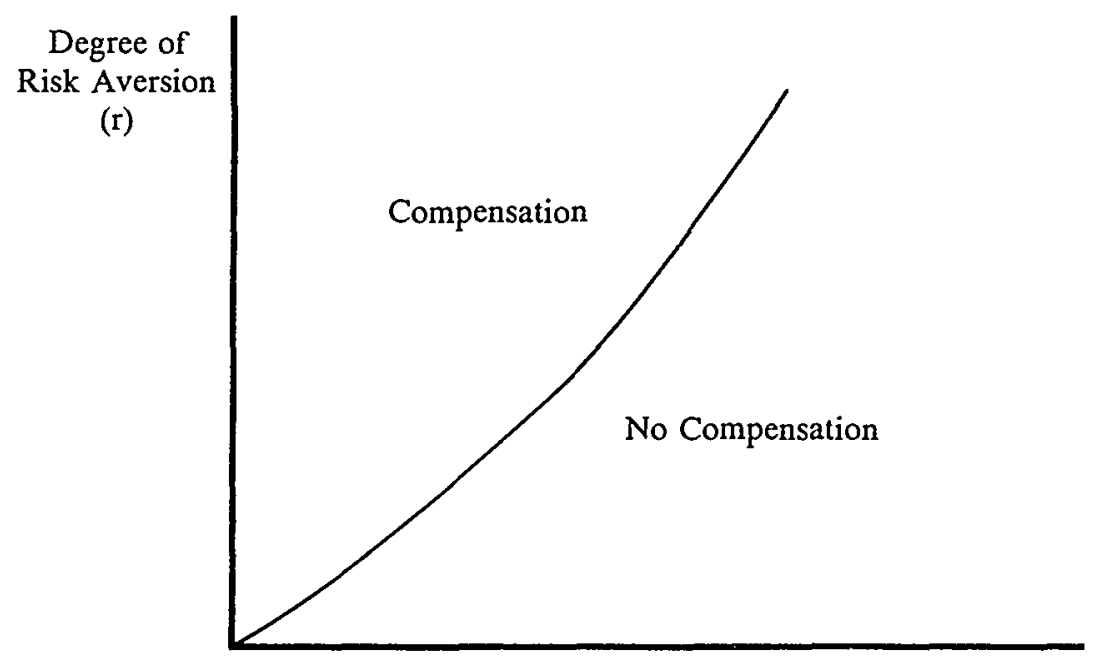

Cost of Administration (c)

percentage of his wealth as his wealth changes. ${ }^{98}$ Consider, for example, a guarantee of a five-percent increase in wealth, versus a gamble with a 0.6 probability of a ten-percent increase in wealth. With decreasing relative risk aversion, the individual is inore likely to take this gamble as his wealth increases. The general view lield by economists is that absolute risk aversion declines with wealth. There is less agreement about relative risk aversion, but many of the results are consistent with the view that relative risk aversion is either constant or declines with wealth. 99

98. If $u$ is the individual utility function, the ineasure of absolute risk aversion is usually taken to be $-u^{\prime \prime} / u^{\prime}$, while relative risk aversion is given by $-w u^{\prime \prime} / u^{\prime}$, where $w$ is individual wealth.

99. The basic definitions of risk aversion appear in K. ARROW, ESSAYS IN THE THEORY OF R1SK-BEARING (1971) (especially pages 103-04). Support for the view that absolute risk aversion declines with wealth is given by H. RAIFFA, DECISION ANALYSIS: INTRODUCTORY LECTURES ON Cho1Ce UNDer UncertainTy (1968); Hicks, Liquidity, 72 Econ. J. 787 (1962); Pratt, Risk Aversion in the Small and in the Large, 32 EconomeTrica 122 (1964); Yaari, Some Remarks on Measures of Risk Aversion and on Their Uses, $3 \mathrm{~J}$. ECON. THEORY 315 (1969). For a discussion of the evidence concerning relative risk aversion, see Cohn, Lewellen, Lease \& Schlarbaum, Individual Investor Risk Aversion and Investment Portfolio Composition, 30 J. FIN. 605 (1975); Friend \& Blume, The Demand for Risky Assets, 65 AM. EcoN. REv. 900 (1975); Grossman \& Shiller, The Determinants of the Variability of Stock Market Prices, 71 AM. Econ. Rev. 222 (1981). For more general discussions of the implications of differing assumptions about risk aversion, see J. HEY, UnCERTAINTY In Microeconomics (1979); Arrow, Alternative Approaches to the Theory of Choice in Risk-Taking Situations, 19 EconometricA 404 (1951); Block \& Heincke, The Allocation of Effort Under Uncertainty: The Case of Risk-averse Behavior, 81 J. PoL. EcoN. 376 (1973); Diamond \& Stiglitz, Increases in Risk and in Risk Aversion, 8 J. ECoN. THEORY 337 (1974); Dyer \& Sarin, Relative Risk Aversion, 28 MGMT. Sc1. 875 (1982); Flemming, The Utility of Wealth and 
We will return to the important issue of the relationship between risk and wealth. First, however, we can see how differences in risk aversion for individuals of identical wealth can affect their willingness to pay for insurance. Such a comparision is illustrated in Figure 2. ${ }^{100}$

The vertical axis represents a measure of the degree of risk aversion of private investors in land. The higher the value of $r$, the greater the extent of risk aversion, and the greater the premium that the individual will pay to avoid risk. ${ }^{101}$ We take $r=0$ to represent the riskneutral case.

The horizontal axis measures the cost of administering a compensation program when land values are adversely affected by governmental action. ${ }^{102}$ If there are no administrative costs or other economic costs of compensation, all risk-averse individuals will choose to insure fully and compensation should be provided. ${ }^{103}$ However, as the average administrative cost increases, our compensation rule states that only those who are substantially risk averse would have chosen $e x$ ante to insure privately, and thus only they will be compensated publicly $e x$ post ${ }^{104}$ The "line" is drawn in Figure 2 solely to suggest what a possible trade-off between risk aversion and administrative costs might

the Utility of Windfalls, 36 REv. Econ. \& STATISTICS 55 (1954); Friedman \& Savage, The Utility Analysis of Choices Involving Risk, 56 J. PoL. ECON. 279 (1948); Hakansson, Friedman-Savage Utility Functions Consistent with Risk Aversion, 84 Q.J. Econ. 472 (1970); Imai, Geanakopolos \& Ito, Incomplete Insurance and Absolute Risk Aversion, 8 ECON. LETrERS 107 (1981); Ross, Some Stronger Measures of Risk Aversion in the Small and the Large With Applications, 49 ECONOMETRICA 621 (1981).

100. This diagran was derived in the special case of a quadratic utility function $u(w)=a w-$ $b w^{2}$. In such a case the degree of risk aversion is given by $-u^{\prime \prime}(w) / u^{\prime}(w)=2 b / a$. If the cost of administration of the compensation program is equal to $c$ (for each property insured), and the risk involved is a gain of $n$ with probability 0.5 and a loss of $n$ with probability 0.5 , then the condition under which compensation should be provided is as follows:

$b c^{2}-c(a-2 b w)<b n^{2}$.

For reasonable paraineter values, the diagrain given in Figure 2 is appropriate. Note that this example is used in another context in Variau, supra note 86, at 56.

101. There are several plausible measures of risk aversion that inight be represented by the mdex $r$, and numerous conceptual problems in distinguishing annong them. For details, see sources cited supra note 99.

102. We chose average cost under the assumption that the program must be fully funded (a competitive insurance firm must break even). A more appropriate assumption would distinguish between fixed and average costs, suggesting a two-part pricing scheme so as to choose efficiently the extent that compensation is paid. In addition, we have assumed that the only costs of the program are administrative costs. Finally, we have implicitly assumed that the risk involved remains unchanged throughout this example, and that the cost of administration is independent of the risk involved.

103. This result is proved in the Appendix.

104. This type of argument has been made in other contexts. See, e.g., Mandelker \& Raviv, Investment Banking: An Economic Analysis of Optimal Underwriting Contracts, 32 J. Fin. 683 (1977); Mossin, Aspects of Rational Insurance Purchasing, 76 J. PoL. Econ. 553 (1968); Smith, Optimal Insurance Coverage, 76 J. PoL. Econ. 68 (1968). For further details, see the Appendix. 
be. ${ }^{105}$

As the figure suggests, assuming that costs are held constant, the efficiency principle will award private compensation to those who are most risk averse and in those situations in which the administrative costs are low. It is difficult, of course, to distinguish among individuals on the basis of their degree of risk aversion. However, it does seem reasonable to expect that as one's wealth increases one has a greater opportumity to diversify risk by investing in a broad array of assets. Thus, the compensating body will approximate risk aversion if its decisions to award coinpensation vary imversely with the wealth of the plamtiff. For fixed dollar losses, this is appropriate if there is decreasing absolute risk aversion, and for losses measured as a fraction of wealth, if there is decreasing relative risk aversion. ${ }^{106}$

It is difficult to relate risk aversion and risk premiums to wealth. First, attitudes toward risk might be a function of a host of factors unrelated to wealth, such as education, age, and fainily status. Second, wealth will be difficult to ineasure. For example, if a factory suffers a substantial loss in value due to a regulation, is compensation appropriate? If the factory is owned by an individual who is not able to spread risk by purchasing other assets, then we nnight deem this to be an insurable loss based on our previous argument; but if the factory is owned by a conglomerate or a large firm that is in turn owned by a large number of stockholders, our answer might be different. ${ }^{107}$

\section{B. What Losses Should Be Compensated?}

We have seen there are difficult administrative problems associated with an approach that focuses solely on risk aversion. A more

105. The curvature of the line in Figure 2 which divides those cases in which compensation should be paid and those in which it should not depends upon the nature of the risk aversion involved. Assume, for example, that the utility function represents constant relative risk aversion and that administrative costs are constant. Under reasonable assumptions, the risk premium will increase as the individual becomes more and more risk averse. However, the risk premium will increase at a decreasing rate. Insurance would have been purchased (therefore, compensation will be paid according to our standard) only where the risk premium is greater than or equal to the cost of compensation. Therefore, any index $r$ of the extent of risk aversion must increase more than the increase in the cost of compensation in order for the individual to want to buy insurance. Assuine, for example, that the utility function is reprasented by the function $u(w)=w^{a}$, and $a$ is the coefficient of constant relative risk aversion. The risk premium associated with a risk involvmg a 0.5 probability of winning $x$ and a 0.5 probability of losing $x$ is given by:

Premium $=w^{a}-0.5(w+x)^{a}-0.5(w-x)^{a}$.

Differentiating with respect to $a$, we find a positive first derivative (the risk premium increases) and a negative second derivative (the increase dinimishes with mcreases in $a$ ).

106. See supra text accoinpanying notes 98-99.

107. It is unusual in the law for the wealth of the parties to affect the outcome of the litigation process. For example, the law of negligence in torts makes the wealth of the parties irrelevant to the negligence decision (although the human capital of the plaintiff would be relevant to the damage calculation). 


\section{FIGURE 3}

Size of Loss AND the Cost of Administration

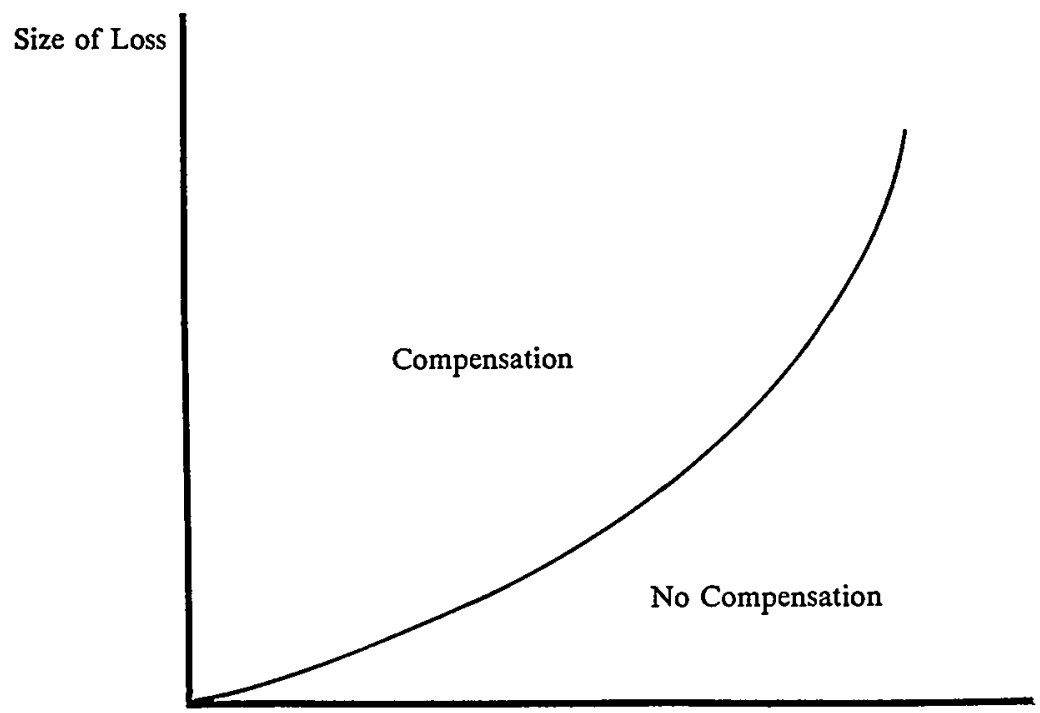

Cost of Administration

useful approach to determining when the compensation should be paid examines the extent to which risk is imposed by the regulatory decision. In the case of decreasing (or constant) relative risk aversion, with fixed administrative costs, mdividuals will choose to insure against risks of the largest magnitude when measured as a fraction of wealth. ${ }^{108}$ This is consistent with the behavior of individuals whose willingness to gamble increases with their wealth. ${ }^{109}$

An exaniple of how the line that separates cases in which coinpensation should be paid from those in which it should not might be drawn is given in Figure 3. ${ }^{10}$ The graph suggests that for a fixed administrative cost, ${ }^{111}$ only those losses which are large relative to wealth ought to

108. This can most easily be seen by examining the insurance condition in the quadratic utility function example presented in supra note 100 . As $n$ increases the risk gets larger, and the individual will choose to insure even with greater costs of administration. Note also that risk is usually measured by the variance of the uncertain event, so that in our example in note 100 , the risk would be given by $1 / 2(n)^{2}+1 / 2(-n)^{2}=n^{2}$.

109. We could argue that the saine approach can be applied to corporations as well as individuals, since corporate managers make allocational decisions which are often consistent with risk aversiou.

110. The grapll utihzes the quadratic utility case, a special case in which the general proposition still holds.

111. A further discussion of the meaning of a fixed administrative cost would be wortliwhile. Clearly the total cost of administration will increase with the number of individual properties to be insured. We assuine that the total cost is to be allocated equally among the individual proper- 
be insured. ${ }^{112}$ If one were to make the further assumption that individual wealth can be approximated by the value of the land involved in the regulatory decision, then compensation ought to be paid only if the government action results in a substantial diminution in the value of the land.

To pursue this point further, it is useful to distinguish between the risk to the individual investor and the risk in terms of a reduction in value of the individual parcel of land. If all parcels of land were owned by different individuals, each with little wealth, then the percentage reduction in the value of land would be closely related to the percentage loss of wealth. However, consider the possibility that a number of parcels are all held by a single wealthy investor. Then a substantial loss on one parcel of land is likely to involve a very sinall loss in terms of the overall wealth of the investor.

In such a case, the efficiency argument suggests that the wealthy investor ought not to be compensated even when an individual property is substantially diminished in value as the result of a government action. ${ }^{113}$ The large investor has simply purchased a number of investments, all of which are risky. But the returns from these investments are essentially independent of the risk of a taking. If there is some risk of regulation, each parcel of land will be purchased at a discount reflecting the valuation of that risk. When an individual purchases a large number of parcels he self-insures. For example, the discounted money would go into a pool of resources that would be sufficient to cover the loss were a taking to occur on any particular parcel. The individual investor cannot be assured in eacli case that the pool will only compensate for losses-there inay be net gams in some cases and net losses in others. However, ex ante, the purchase of a wide variety of assets should substantially diminish the risk that the investor must face. Once again, this is consistent with the argument presented earlier: wealthy individuals are less likely to insure against a given risk. ${ }^{114}$

However, application of the proposed compensation rule is troublesoine. If a plaintiff expects to be successful, she must present evidence about investor wealth and investments. This may prove difficult.

ties, so that the cost per property, the "fixed cost," is constant. It is possible, of course, that the cost of insuring a given property will vary with the nature of the risk to be insured-i.e., that the margimal cost of administration imcreases with risk. Both the fixed cost and marginal cost cases are analyzed in the Appendix.

112. The slope of the curve increases with the cost of adininistration in this case simply because the risk involved is a function of the variance of an uncertain event, which in turn is a function of the square of the loss. The graph relating degree of risk borne versus compensation, however, would be linear.

113. This might create an equity problem, however.

114. Specifically, with decreasing absolute risk aversion, the demand for insurance falls with wealth. For details, see Diannond \& Stiglitz, supra note 99. 
Moreover, the costs of administering such a system may require compensation in fewer cases. In addition, any rule based on wealth might induce wealth-masking responses. For example, large investors might form sinaller corporate entities to invest in risky assets. If the smaller entities do not make independent busmess decisions, then the larger entities are the relevant ones for compensation purposes.

The difficulties in inuplementing a wealth test may lend support to the dimmution in value approach. However, the efficiency approach suggests that a compensation rule based on substantial dininution in value will be efficient only under the following set of conditions. First, individuals' attitudes toward risk nust make them more willing to insure agaimst a given risk the lower their wealth (as with decreasing relative risk aversion). Second, the costs of measuring and paying compensation cannot be related to the magnitude of the risk. Finally, the value of the land affected by the regulatory change must be a "substantial" portion of the wealth of the individual.

What happens if we relax the assumption of constant administrative costs? While we cannot generalize to all possible cases, if adminstrative costs increase substantially along with an increase in the magnitude of the risk, the substantial diminution in value rule becomes highly mefficient. ${ }^{115}$

One might argue that if the taking is foreseeable, the buyer of a parcel of land does not deserve counpensation. The price of the land will fall due to the foreseeable taking, and the buyer is thus compensated ex ante. However, this argument is incorrect. Any reduction in price will only partially compensate. In addition, the price would not fall in the first place were full compensation for a taking available in all cases. Thus, in Example 5, the purchase price for the lot would be $\$ 75,000$ in a no-compensation world and $\$ 100,000$ in a full-compensation world. A risk-neutral investor would be indifferent between the two, but a risk-averse investor would inuch prefer to pay $\$ 100,000$ and avoid the uncertainty associated with regulation. In this case, compensation mcreases economic efficiency because it leaves the seller of the property as well off in both situations, and benefits the buyer, who is

115. An additional problem arises from the fact that mdividuals are concerned about any expected losses that might arise from government action. In other words, they are looking at the problem of risk ex ante. They subjectively determine a probability that a given government action will affect the value of their land, and if the action oceurs, what the damage will be. Generally, insurance will be demanded by those who face large expected damages, that is, in cases in which the probability of a loss is deemed to be large ex ante, or the amount of the loss will be large relative to wealth. Thus, an ideal rule requires compensation if, at the time the individual purchased the parcel of land, he or she could have reasonably expected a "taking" to occur, or if the damage or loss could reasonably be expected to be relatively large. Such a rule is not likely to be practical simce it involves a determination of the investor's perceptions at the time the land was purchased. 
willing to pay something to avoid risk. ${ }^{116}$

Should a substantial loss be compensated if it was unforeseeable? This is closely related to the foreseeability problem im tort law. ${ }^{117}$ Under current doctrine, if an event is unforeseeable, no damages need be paid for a neghigent act. This rule is efficient because the absence of compensation will not affect individual behavior concerning unforeseeable events. However, if the event is foreseeable and tortfeasors are not hable for lack of care, they will have no incentive to avoid a preventable harm. This is an inefficient result. ${ }^{118}$

This discussion of substantial diminution of value is not limited to regulatory takings. If the government physically takes only a portion of a parcel, there is a complete loss of value of the portion taken, but the total value of the parcel of land may not fall substantially. The above argument suggests that efficiency does not require compensation for such governmental action. Likewise, physical mvasion of airspace, as in Causby, ${ }^{119}$ need not be compensated if the impact on property values is not great.

\section{Some Legal Examples}

The efficiency approach to compensation provides a coherent framework in which compensation payment can be evaluated. The following rather brief discussion of some recent cases suggests how such an evaluation imght be done. In each case, two conditions must be satisfied im order for compensation to be efficient. First, the loss must be substantial. The loss is considered substantial if it significantly

116. Should compensation be paid for value enhancing changes in zoning regulations that the purchaser reasonably expected to occur when he bought the property, but did not occur in the expected period of time? One could argue that a loss in land value has occurred, at least when viewed in relation to reasonable expectations. There is little difference in the abstract between compensation for actual regulation and compensation for the absence of regulation. However, practical problems suggest that the two situations should be treated differently. Compensation for disappointed expectations would require either an objective standard or an inquiry into the subjective intent of the landowner at the time of the purchase. The latter would be a potentially costly and difficult procedure. Of course, compensation for actual change does not totally avoid these problems, since it involves an assumption about what information was available at the time of the initial purchase.

117. See, e.g., Shavell, An Analysis of Causation and the Scope of Liability in the Law of Torts, 9 J. Legal STUD. 463 (1980).

118. Of course, this conclusion depends upon an assumption that the premiums paid through the tax system to cover compensation would not in themselves distort decisions (given a compensation rule that focused on foreseeability). For example, if the premiums were paid by all landowners, but only certain types of land uses were likely to yield foreseeable regulatory changes, then investors might have an inccntive to buy where the harm was foreseeable simply to eliminate risk.

119. United States v. Causby, 328 U.S. 256 (1976). In Causby, however, the Court did deem recurrent flights through the airspace of a chicken farm to be a taking. See supra text accompanying note 26. 
reduces the owner's net worth. Second, the party that is harmed must be substantially averse to risk. In general, we will assume that the more wealthy the plaintiff, the less likely that she will be risk averse (im relative terms).

In Penn Central, ${ }^{120}$ the owner of Grand Central Station argued that the loss of the right to construct an office building over the station substantially diminished the value of the site. ${ }^{121}$ Although the actual reduction in value was in dispute, let us assune that it was substantial. ${ }^{122}$ Under the efficiency theory, it is irrelevant that the loss was attributed to disappointed expectations concerning the right to a ncw use for the land, rather than a required change in the current use of the land. Either type of loss, if substantial, is a risk that can lead to efficiency losses if no coinpensation is available.

The Supreine Court's analysis of Penn Central's loss was counplicated by the city's partial coinpensation of Penn Central. The city gave transferrable developinent rights (TDR's) to Penn Central to compensate partially for the loss of its developinent rights over the station. If the TDR's were valuable enough to offset substantially the loss of developinent rights, then coinpensation is unnecessary, since the loss was not substantial. ${ }^{123}$ However, the value of the TDR's to Penn Central is not clear. The TDR's were valuable to Penn Central only if they gave the coinpany a right to develop that it would not otherwise have had. ${ }^{124}$ Since the analysis would be settled otherwise, we assume that the TDR's had hittle value, and that the loss to Penn Central was substantial. Thus, for the purposes of this analysis, the first criterion necessary for a taking under the efficiency approach is satisfied.

The second part of the coinpensation rule asks whether Penn Central was sufficiently risk averse to be an appropriate candidate for compensation. We would tentatively answer this question in the

120. Penn Cent. Transp. Co. v. New York City, 438 U.S. 104 (1978).

121. Actually, there were two plaintifis in the case, Penn Central and the lessee of the property, UGP Properties, Inc. (UGP). "UGP promised to pay Penn Central \$I million annually - during construction and at least $\$ 3$ million annually thereafter. The rentals would be ofiset im part by a loss of some $\$ 700,000$ to $\$ 1$ million in net rentals presently received from concessionaires displaced by the new building." Id. at 116.

122. The loss in value is reflected by the lost profits associated with the planned construction. See supra note 121 .

123. One might object to the TDR approach since it manages indirectly to legitimate partial compensation, an approach that is apparently imconsistent with most interpretations of the fifth amendment.

124. "Under New York City's zoning laws, owners of real property who have not developed their property to the full extent permitted by the applicable zoning laws are allowed to transfer developinent rights to contiguous parcels on the same city block." 438 U.S. at 113-14. One might argue that Penn Central had the right to develop the neighboring properties irrespective of the Court's view, if the restriction or elimination of those rights would be (from the plaintiff's point of view) a taking. 
negative. ${ }^{125}$ The record shows that Penn Central is a corporation with substantial assets, including a number of parcels of land other than the station. ${ }^{126}$ A large portfolio of assets facilitates the company's diversification to protect against the risk of changes in land use regulation. This is especially true since Penn Central owned several parcels, and the likelihood of inore than one being declared a historical landmark is quite small.

Thus, the efficiency analysis leads us to conclude that there was not a taking requiring compensation in Penn Central, regardless of the TDR's value. A plaintiff inust satisfy both prongs of the two-part test in order for compensation to be efficient. In this situation, Penn Central fails the second prong.

In HFH, Ltd. v. Superior Court, ${ }^{127}$ the plaintiffs, a limited partnership and a corporation, were the owners of a 5.87 acre parcel. At the time of the contract to purchase the land, it was unimproved and zoned for agricultural use. The plaintiffs conditioned their purchase, requiring the seller to obtain conimercial zoning for the tract. The conimercial zoning classification was granted, and the purchase was completed.

Five years after the purchase, the land reinained unimproved and the city placed a unoratoriun upon more intensive-for example, cominercial-uses of the land. The following year plaimtiffs entered into a contract to sell the land for $\$ 400,000$, a $\$ 12,000$ gain over their original purchase price. The sale, however, was agam conditioned upon reclassification of the land as commercial. Plaintiffs' apphication for cominercial zoning was rejected in favor of a single family residential classification. At the same tinne, however, the city zoned other properties abutting plaintiffs' land for counmercial use. Plaintiffs contended that their properties were useless for residential purposes, and that as a consequence, the value of their property had fallen to $\$ 75,000$. Plamtiffs filed an inverse condemnation action and the California Supreme Court held that their counplaint did not state a cause of action. ${ }^{128}$

The facts of $H F H$ suggest a strong argument for compensation, especially in the case of the limited partnership. We first assume that the plaintiffs correctly alleged a decline in the market value of the tract to $\$ 75,000$. In addition, if the $\$ 400,000$ selling price accurately reflected

125. A more satisfying answer would depend upon a careful analysis of the financial status of the corporation and its investments, an analysis not undertaken by the Court.

126. The neighboring properties owned by Penn Central mcluded the Biltmore Hotel and the Waldorf-Astoria.

127. 15 Cal. 3d 508, 542 P.2d 237, 125 Cal. Rptr. 365 (1975).

128. As in Penn Central, the plaintiffs did uot claim that there was a nonconforming use involved. Rather, they asserted a right to the zoning classification. This distinction was inportant to the court, see id . at 516 n.12, 542 P.2d at 242 n.12, 125 Cal. Rptr. at 370 n.12, but is unimportant for the efficiency approach espoused here. 
the market, ${ }^{129}$ then the rezoning was apparently the direct cause of the diminution in value. The $81.25 \%$ decline in value is sufficient to satisfy the first part of the compensation test-substantial diminution in value.

In this case, it is difficult to assess the second prong of the efficiency compensation test-the plaintiffs' risk aversion. If both plaintiffs were so small (im terms of wealth) that they could not diversify the risk of regulation by investing in other real property and other types of mvestments, they satisfy the second part of the compensation test as well. ${ }^{130}$ Unfortunately the record is not sufficiently clear on the question of wealth; thus a definitive conclusion calmot be reached. ${ }^{131}$

In Loretto v. Teleprompter Manhattan CATV Corp. ${ }^{132}$ the Supreme Court ruled that a relatively minor but permanent physical occupation of an owner's property constituted a taking and required full compensation. Plaintiff, the owner of an apartment building in New York City, brought a class action agamst the defendant cable television companies, after discovering that the cable installation occupied portions of her roof and the side of her building. The Court focused on the permanent nature of the physical invasion, stating that a property owner has a strong expectation of compensation. ${ }^{133}$ This expectation should not be thwarted when a permanent physical invasion is involved. The niajority opimion noted that the character of such a physical invasion is substantially different from other types of property regulation and that therefore a substantial loss in value is not required to find a taking. ${ }^{134}$

While the opinion of the Court does not provide complete information, a more thorough analysis of the case from the efficiency viewpoint leads to the conclusion that compensation is inappropriate. A

129. It is important (and somewhat unclear from the stated facts of the case) that factors unrelated to the zoning change did not cause the value of the land to change from the time of purchase to the time of the lawsuit. In addition, the $\$ 400,000$ must represent the value as determined in an arm's-length transactiou.

130. The court stated that changes in zoning law ought to be foreseeable to land speculators and purchasers of property in general, and therefore, ought not to be compensated. $15 \mathrm{Cal}$. $3 \mathrm{~d}$ at 521, 542 P.2d at 246, 125 Cal. Rptr. at 374. The court's argumeut is, however, overly broad, see supra text accompanymg notes $63-73$, since the ability to foresee that land use regulations will change does not elimimate the risk that investors face.

131. The court does not seem totally unsympathetic to compensation but states that there is currently no basis for ordering compensation in sucl a situation. A reinterpretation of the state constitution would have been required, but the court chose not to render one. Rather, it stated that plaintiffs desired the court to "redefine the state and federal constitutioual requirements of just compensation and to require payment for any zoning action which results in the substantial diminution of market value," and that its failure to do so was based on its "conviction that legislative rather than judicial action holds the key to any useful reforn." Id. at 521, 542 P.2d at 246-47, 125 Cal. Rptr. at 374-75.

132. 102 S. Ct. 3164 (1982).

133. Id at 3179 .

134. Id. at 3174-76. 
physical invasion is irrelevant to the efficiency determination. The presence of cable equipment is equally likely to increase or decrease the market value of the property, and any losses are better characterized as psychological losses on the part of the plaintiff. ${ }^{135}$ The two-part test requires: (a) a substantial loss, and (b) a risk-averse plaintiff. In this case, the loss in market value was clearly not substantial, and the loss in subjective or psychological value is too problematic. Thus, the first part of the test is not satisfied. ${ }^{136}$ Since the second part of the test is imsufficient on its own, compensation should not be awarded.

However, the Court states that a no-compensation ruling would conflict with the expectations of the plaintiff. Yet disappointed expectations are neither necessary nor sufficient for efficient compensation, although disappointed expectations are often present in cases where we would compensate for reasons of efficiency. A clearly stated policy of no compensation, articulated either by the courts or legislature (ignoring constitutional requirements), would eliminate disappointed expectations (with respect to compensation).

Although somewhat brief, this analysis demonstrates the manner in which we envision courts employing the efficiency analysis. The analysis, consisting of two necessary steps, represents an approach that could be integrated into the present judicial approach to the takings question.

\section{Will Compensation Distort Relative Land Use Decisions?}

In any government compensation scheme, the revenues from which compensation is paid must be collected by a method that ensures a balanced budget. Were this not the case, implicit subsidies would exist, causing distortions in land use. This is especially important because there is a large cost associated with any scheme that expands compensation beyond a relatively narrow set of cases.

This cost is demonstrated in the following example. Example 6

A community contains a substantial number of residences, each located on a parcel of land subject to frequent zoning changes. A number of these zoning changes substantially diminish the value of the residences. The residences make up fifty percent of the value of the property tax base in the community, and the remaining fifty percent in

135. The magnitude of the loss involved in Loretto (if there was any) was left undeternined, as the case was remanded to the lower courts.

136. Loss of subjective value ought to be included in the decision to compensate, as well as in the determination of the amount of compensation. See infra text accompanying notes 147-48. However, the measurement of subjective value is sufficiently difficult as to be intractable if a working compensation rule is to be developed and applied in a large number of situations. 
value is associated with a large industrial plant. The plant has been located in the community for sone time and it is vital to the health of the local economy. As a result, there have not been any zoning changes that adversely affect the plant and none are expected.

If the revenues that fund the coinpensation schenie are generated by an increase in the tax rate covering all property in the community, then the industrial plant will be subsidizing the insurance, which protects only owners of residential properties. The plant pays taxes each year, but receives no benefits, while the cost of insurance to the residential properties is one-half (on average) the actuarially fair cost of market-based insurance.

Such subsidies can generate inefficient land use. This inefficiency will occur if either: (a) more individuals choose to live in the community because of the subsidized insurance; or (b) those individuals who currently live in the community make additional improvements to their houses solely due to the insurance subsidy.

Our conclusion comes in two parts. First, if conpensation will be available in more than just physical invasion cases, the kinds of events that are likely to lead to the payment of coinpensation must be defined. In addition, charges for the compensation prograin must be structured in a way that ensures that individuals most likely to receive compensation will be taxed. Thus, if most regulations will affect commercialindustrial property of a certain type, property tax assessnients will have to be directed at the appropriate parcels. This might be achieved, for example, through special assessments or through tax rates which differ according to the class of property.

Second, the risk of land use distortions may indicate that the cost of compensatimg more than just physical invasions is too high. Without special assessnients or differential tax rates, distortions caused by the prospect of compensation nuay outweigh any gains achieved by the elimination of risk. ${ }^{137}$

This special assessment approach was implemented in a somewhat different context by several states and cities. The project was known as ZSAFED, or "zoning by special assessment financed emment domam." 138 ZSAFED worked outside the conventional zoning process. If a majority of homeowners petitioned to have an area zoned strictly residential, the city levied special assessments on those who benefited from the restriction (homeowners) in order to compensate those who lost (owners of land that was previously zoned for commercial develop-

137. It is also possible that the compensation will subsidize liome ownership, and thus implicitly penalize renters.

138. One state that utilized ZSAFED was Minnesota. See MinN. STAT. ANN. $\S 462.14(5)$ (West 1963) (enacted in 1915). 
ment). ${ }^{139}$ However, once the constitutionahty of zoning without the payment of compensation was determmed in Village of Euclid $v$. Ambler Realty Co. ${ }^{140}$ cities moved away from the special assessment approach. ${ }^{141}$

\section{E. A Risk-Averse Government?}

Our analysis of the governmental decision to provide insurance has assumed that the government can spread all risk-in effect allowing itself to act without regard to risk. To make the analysis more reahstic, we must take into account the fact that the government is likely to behave in a risk-averse manner. There are two reasons for this. First, the governmental body represents the constituent voters, who are theinselves largely risk averse. Thus the government body may act as if it is risk averse. Second, the government cannot provide an unlimited anount of insurance through compensation. It has limited funds available, and the risks associated with the government action cannot be shifted coinpletely to risk-neutral parties. Unhike an insurance policy for whole life coverage on a large group of unrelated individuals, the risk of zoning changes is not easily spread among the population. Rather, adverse zoning decisions are likely to affeet a large nuinber of landowners within the jurisdiction. Thus, the risks of loss borne by the landowners are not independent of each other, and diversification is no longer possible.

Assume for the moinent that the possibility of soine diversification allows the government to act in a less risk-averse manner than its constituents. Then, the range of possible compensation changes somewhat from that illustrated in Figure 3. The change in the analysis depends upon whether the government is constramed by law to coinpensate fully for all losses (for example, by providing full-coverage insurance).

If full compensation is required, then Figure 4 suggests how a riskaverse government will restrict the range of efficient compensation. ${ }^{142}$ The area between the dotted and solid lines represents the range in which the benefits froin compensation only slightly outweigh the costs witl a risk-neutral government. With risk aversion, tliere is a cost to the government of providing msurance, which varies linearly with the risk and nonlinearly with the inagnitude of the prospective loss. This

139. See R. ElLICKSON \& A. TARLOCK, supra note 7, at 693-94.

140. 272 U.S. 365 (1926).

141. For further details, see D. HAGMAN \& D. MisczYNSKI, WindFALlS For Wipeouts 65354 (1978).

142. If the government's "utility function" is $u(w)=f w-g w^{2}$, then the insurance condition given in note 100 becomes

$b c^{2}-c(2-2 b w)<(b-g) n^{2}$.

This example was used to construct Figure 4. 
FIGURE 4

Size of Loss and the Cost of Administration With a RISK-AVERSE GOVERNMENT

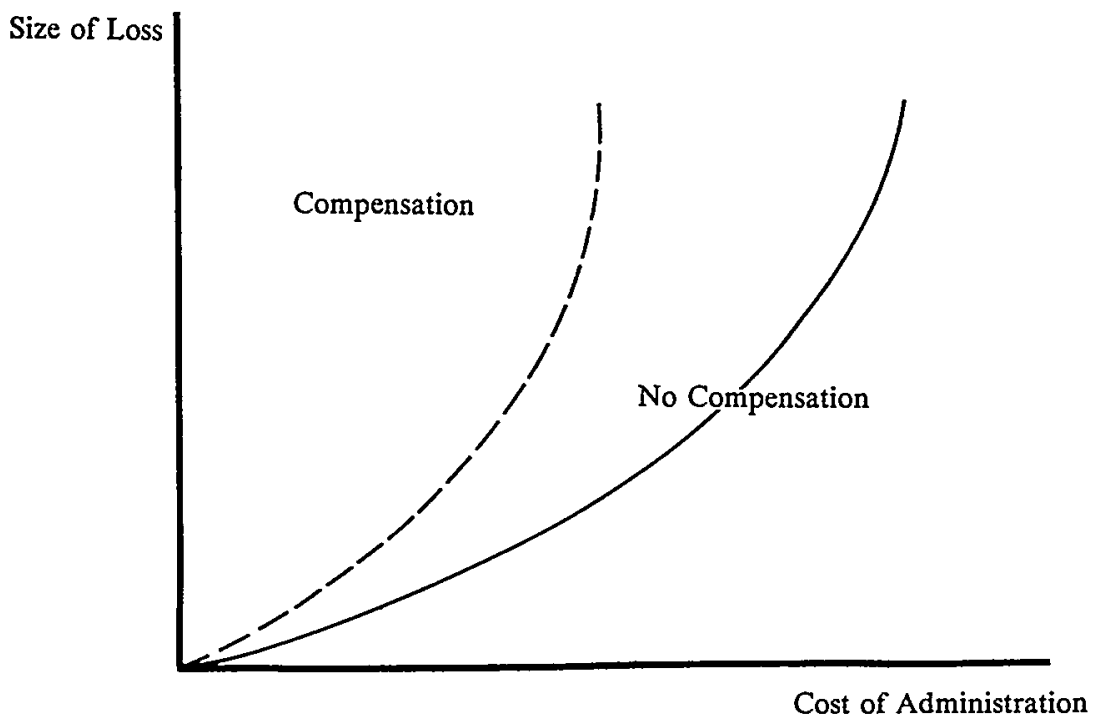

cost reflects the fact that the constituents as a whole do not enjoy bearing risk and, therefore, do not want to expend resources in compensating themselves as individuals. Thus, for a small range in which compensation was once deeined valuable, we would expect no coinpensation to be paid. ${ }^{143}$

When the governinent is risk averse, full insurance will not necessarily be the efficient outcoine. Under full insurance, private investors face no risk, and government faces all of the risk. However, if both the individual investor and the government are risk averse, an allocation of risk among the parties will be the unost efficient result. This allocation can minimize the total cost of the risk, viewed in terms of lost utility to the individuals. Allocation involves risk-sharmg, with the inore riskaverse individual (other things being equal) bearmg less risk.

Thus, if government is risk averse, partial coinpensation may be appropriate. Indeed, if government is risk averse, full compensation will be socially inefficient. This approach is analogous to the theory of risk spreading in tort law. One of the advantages of a coinparative neghigence rule, in contrast to contributory negligence or strict liability,

143. The diagram is drawn under the assumption that this no-compensation range will be severely limited when the cost of administration is large and the size of the loss is large. This is consistent with the case in which the government has decreasing relative risk aversion. 
is that the risks associated with an accident are borne in part by both the injurers and the victims.

\section{MEASURING COMPENSATION}

The difficulty of determining the appropriate amount of compensation has plagued many commentators. ${ }^{144}$ However, consideration of the incentive effects of full compensation reveals that full compensation is in general an mappropriate compensation measure. To make the analysis as clear as possible, we treat the extreme situation in which the government physically takes a parcel of land, and in the process, destroys all of the structures on it. This allows us to avoid the problem of reducing compensation when capital can be used at alternative sites.

First, consider a situation where individuals would not imsure. Compensation of current market value provides full imsurance against the risks of regulatory takings. But if the government is providing useful public projects, and if the "taking" of the land and the destruction of the structures on it imvolve a real cost to society, then full imsurance is not necessarily efficient. Knowing that full imsurance is available, private investors will tend to put too much of their physical capital on "risky" land, and too little on land that will be unaffected by the government decision. They can afford to "overinvest," because they know that any losses will be compensated. ${ }^{145}$ Since it is efficient for society when mdividual mvestors take account of the risk of government action in investment decisions, msurance can alter and distort private investment decisions.

Does this argument turn our earlier argument for compensation on its head? Earlier in this Article, we argued that compensation ought to be provided only if the benefit associated with the reduction of risk outweighs the administrative cost of providing compensation. However, the problem and the distinction he in the measure of compensation.

"Current" market value as we have defined it is an inappropriate measure of compensation. Even if msurance is provided, it ought to be based on the value of the land as it would have been developed had the

144. Whatever the exact determination of compensation, it is important that the measure be one that cannot be directly affected by the behavior of the individual investors, since any compensation measure which can be affected by private behavior will create the possibility of inefficiency due to moral hazard. For complete details of this argument, see Blume, Rubinfeld \& Shapiro, The Taking of Land: When Should Compensation Be Paid?, 99 Q.J. EcoN. 71 (1984). For an arguinent suggesting that the condemnee has a dnty to mitigate the government's damages, see Merced Irrigation Dist. v. Woolstenhulme, 4 Cal. 3d 478, 483 P.2d 1, 93 Cal. Rptr. 833 (1971).

145. This argument would be unlikely to apply to individual houneowners whose primary purpose in buying a home is consuinption rather that investment. 
government not been expected to pay compensation. If current market value is used as a measure of compensation, then any additional investment due solely to the availability of compensation will be included as a part of the compensation payment. This overinvestment due to the presence of compensation is inefficient and should not be encouraged.

As an example, imagine a restaurant owner who builds a restaurant on land located in the probable path of a proposed highway. If the restaurant owner knows that coinpensation will be paid at full market value, he can expand the restaurant without fear of loss due to a taking. ${ }^{146}$ When the land is taken, although the physical structure of the land may be destroyed, the restaurant owner can nove the "goodwill" he has gamed through his additional investment to another location. Thus, overinvestment is encouraged because the loss due to a taking is fully imsured at current value. The appropriate approach in such a case is compensation only for the market value of the land unaffected by the availability of full insurance.

Measuring compensation is a very complex problem. A court must determine how the land would have been utilized had the investors not responded to the availability of compensation. This problem also suggests that compensation based on market value at the announcement of the taking is mappropriate, since investors may have acted on knowledge available prior to the actual announcement. ${ }^{147}$

$U p$ to this point, some measure of market value has been assumed to yield the appropriate compensation measure. However, there are at least two reasons why one might go beyond a measure of market value to determine compensation. First, take the classic case in which an individual parcel of land has a unique subjective value to the owner. Such subjective utility cannot be assigned a dollar value in the market. For example, an individual living in an old family home, passed on for generations, might value that home substantially more than would any other purchaser. In principle, the appropriate compensation measure ought to include the umique value of tlie land to the individual. Otherwise, if compensation is offered only at market value, the government does not have the appropriate incentive to avoid regulating or taking properties that are highly valued for "unique" reasons. ${ }^{148}$

146. If he is a risk-averse investor he will fear that no taking will occur, and this will discourage to soine extent the possibility of his overinvesting.

147. However, compensation should be lower for those who purchase after the announcennent is made.

148. This conclusion is based on a value-maximizing norn in which dollar values associated with costs and benefits are added, and in which interpersonal comparisons of utility are allowed. If we did not allow interpersonal comparisons, the conclusion would not necessarily follow, since it would be impossible to compare the loss of subjective vaIne to one individual to the gains made by other residents of the community. 
Market value is also relevant to estimating an individual's willingness to pay for compensation. In some cases, the ainount a landowner will pay to avoid a taking will not equal the payment necessary to make him whole after a taking. ${ }^{149}$ When subjective value is not involved, the latter measure is equal to the market value. However, all takings involve transaction costs, moving costs, and psychic costs. The willingness to pay to avoid a taking is likely to incorporate these costs; market value $\mathrm{m}$ general will not. While neither is necessarily a better measure of compensation, the amount a landowner is willing to pay to avoid a taking is a more plausible measure of the appropriate compensation. By forcing the government to compensate based upon a landowner's willingness to avoid a taking, the full social costs, including transaction costs, of the taking will be borne by the government.

However, both of these suggested changes in coinpensation move away from market value, which can be measured with relative ease. Both measures of value suggested-the unique value of the land, and the willingness to pay to avoid the taking-are difficult to ascertain, and thus add to administrative costs. In fact, individuals have an incentive to misrepresent both their subjective valuation of the land and their desire to avoid a taking. Thus, market value may be an appropriate compromise measure for compensation. However, even true market value ought to be viewed as a "second-best" atteinpt to measure the appropriate level of compensation.

\section{VI \\ The Possibility of Government Failure}

\section{A. Fiscal Illusion}

In a truly efficient system, decisionmaking bodies must account for the full social costs of their actions. Budgetary outlays should not, in principle, affect the public decision any inore than other social costs. However, decisions are often skewed by attempts to avoid nonetary expenditures which appear in the budget. Therefore, it is iniportant to consider the possibility that a change in the compensation rule will alter the outcome of the regulatory process (and will affect the use of the eminent domam power as well).

The usual point of departure for consideration of this question is the now extensive hiterature on "public choice." One of the important

149. See, e.g., H. Varian, Microeconomic Theory (2d ed. 1982). See also Knetsch \& Borcherding, Expropriation of Private Property and the Basis for Compensation, 29 U. TORONTO L.J. 237 (1979). This difference is standard in economic theory-the difference between compensating variation (the maximum amount that would be paid to avoid the taking) and equivalent variation (the inaximum amount that the individual unust be paid after a taking to make him whole). 
themes of the public choice literature is that the provision of goods and services by the public sector may not be economically efficient. The efficient outcome weighs individual preferences according to willingness to pay for government output-usually measured in dollars. However, the political outcome is a result of either a majority rule or a representative process. In majority rule, votes are weighted equally. In the representative process, the government body, such as a zoning board, is sensitive to the pressures of interest groups; such sensitivity is unlikely to be related to the strengtli of the preferences of all the commumity's residents.

According to this view of the political process, a governmental regulatory body will over- or under-regulate if it does not consider all budgetary and social costs. The actual result depends upon the distribution of individual tastes and political influence within the commumity. As applied to the land market, if the governmental body responsible for zoning decisions does not pay compensation, it cannot make socially beneficial decisions. ${ }^{150}$

In other words, the governmental body is subject to "fiscal illusion." 151 Fiscal illusion arises because the costs of governmental actions are generally discounted by the decisioninaking body unless they explicitly appear as a budgetary expense. ${ }^{152}$ Compensation renoves fiscal illusion because it requires a budgetary outlay. It can thus serve as a corrective device for governmental failure. However, the argument for compensation cannot possibly correct any "across the board" fiscal illusion problems. Only those costs ignored by the decisionnaker should be compensated. If there is partial fiscal illusion, partial compensation will be appropriate. ${ }^{153}$ In general, only if the government completely disregards all nonbudgetary costs and correctly values all benefits should full coinpensation be paid. Thus, full compensation is not necessarily an efficient corrective device for governmental failure.

Fiscal illusion is a problem of uncertain boundaries. Fiscal illusion might become a much larger problein as the dollar cost of a pro-

150. This view is described in Courant, Gramlich \& Rubinfeld, The Stimulative Effects of Intergovernmental Grants: or Why Money Sticks Where It Hits, in FISCAL FEDERALISM AND Grants-IN-Aid 5 (P. Mieszkowski \& W. Oakland eds. 1979) (Coupe Papers on Public Economics, No. 1.); see also Ellickson, Suburban Growth Controls: An Economic and Legal Analysis, 86 YALE L.J. 385, 420 (1977).

151. See the discussion of the "flypaper" effect in Courant, Gramlich \& Rubinfeld, supra note 150 , at 6 .

152. In our terminology, such illusion is a mark of government failure, although it may be the result of rational political planning. An appropriate zoning board or other decision should be based on the trade-off of all costs and benefits of the decision, independent of any budgetary commitments that are involved.

153. Correspondingly, if the government action inposes costs on the landowner that are not refiected in land values, more than full compensation could be required. 
ject grows. Thus, our previous compensation rule might require expansion: compensation is also appropriate if the project is above a certam critical size. On the other hand, the greater the dollar cost, the more the regulated party will desire to educate the regulator in order to forestall the project.

A more careful examination of the nature of the project involved (an effort beyond the scope of this Article) might suggest a more complex explanation of the fiscal illusion phenomenon. For example, if the government project involves the construction of a highway or public building, fiscal illusion or pohtical influence might play a major part im project approval. In such a case, the decisionmaker faces a project with visible and clearly defined benefits which can be held up to voters at reelection time. However, the taxes necessary to finance the budgetary outlays are less likely to be noticeable to the electorate, since tax imcreases can occur after the election.

If the government is involved in the regulation of externatities, in which one party gams at the expense of another, the fiscal illusion problem is likely to be less severe. When those who gam and those who lose are equally likely to affect the outcome of the next election, the decisionmaker will be mclined to make the cost-benefit decision correctly. Thus, the extent to which the benefits of the project are concentrated among an "influential" group of voters or potential voters can be a key determinant of the presence of fiscal illusion.

\section{B. Project Choice and Moral Hazard}

The appropriate measure of compensation is the market value that the land would have had if the behavior of all of the parties had not been affected by the certainty of compensation. However, if current market value is used as the measure of compensation (and therefore as one measure of the costs of the project in the government's project choice calculation), then a moral hazard problem can arise. This moral hazard may result in mefficient regulation. As noted above, if full compensation at current market value is available, mdividuals might be induced to overinvest in land. Similarly, the use of current market value also offers the individual investor a chance to affect the project decision. If the project decision is based on the conclusion that benefits outweigh costs, and in particular if the project involves a choice of alternative locations, then private investors can alter the costs to the government and thereby alter project choices.

Imagine two parcels, both of which are close substitutes for the project. The investor in the first parcel is induced to imvest capital in his land, raismg its "current" market value and thereby requiring greater compensation. If the government project decisionmaker re- 
sponds to this change in private investment, he may choose to take (inefficiently) the second parcel. Once the investment in the first parcel has occurred, it is efficient to choose the second parcel. However, the inefficiency arises because the government will incorrectly evaluate its land use regulation projects in the future. Had the appropriate ineasure of compensation been set, the additional capital would not have been invested in the first parcel, and the inefficiency would be renoved.

Our presentation of distortions in government project choice is not yet complete. If there were no transaction costs, then all owners of land might overinvest to discourage the likelihood of a taking. While this may be an interesting theoretical issue, it is not very important in practice due to transaction costs and risk aversion. However, the inajor point of our argument still stands: the measure of compensation should be based on the most efficient use of the land and not on its current market value. ${ }^{154}$

\section{SOME CONCLUSIONS}

The usual reinedy in a takings case is invalidation of the regulation at issue. Recovery of damages in an inverse condemnation proceeding is rare and is usually limited to cases in which there is a physical invasion of the land. When land values are affected by regulation that does not involve physical invasion, damages are usually not available. This Article suggests that, at least on economic grounds, the distinction between physical and regulatory takings is not a particularly

154. Who should compensate? The assumption implicitly made has been that the government doing the taking ought to be doing the compensating. If we are referring to local regulations, it is interesting to ask whether the local government is the appropriate compensating body. Specifically, we should consider the trade-off involved in compensating at the local as opposed to the state or federal level. Compensating at the state or federal level presents the coinpensatimg body a greater opportunity to diversify risk, and therefore to lower the premium associated with the provision of insurance. Other things being equal, federal government insurance is cheaper than local government insurance from a risk-spreading point of view.

There is one substantial disadvantage to compensating at the federal level. The compensating body is likely to raise its revenues from a inuch wider jurisdiction than the one directly affected by any zoning or regulatory change. This would increase the possibility of government failure at the local level, since the local jurisdiction would not face any of the budgetary costs of its actions.

Payment of coinpensation at the federal level also seems counter to the usual notion that compensation can spread the costs of the government action among the individuals in the jurisdiction who are likely to benefit by the activity of the government. After all, compensation is simply a ineans of shifting the cost from certain individuals to all taxpaying inembers of the commumity. Federal or state coverage for compensation creates a sort of "community moral hazard," in which individual communities might be encouraged to undertake activities which would require compensation, because of the distributive nature of the funding arrangement. Thus, while federal or state provision of compensation does have advantages in terms of diversification of risk, these advantages are likely to be outweighed by the fact that costs are borne by a different level of government than are the benefits. 
useful one. The regulation remedy should no longer simply be one of invalidation, but one of compensation as well.

Apart from any considerations of equity, compensation can improve the efficiency of the land market by eliminatimg some or all of the risk of governmental regulation that risk-averse landowners face. This reduction of risk will also reduce any distortions im land use decisions that are created by differing attitudes toward risk. The risk-insurance approach to the taking question can provide a theoretical foundation upon which support for the diminution in value compensation theory can be built. With individuals who have decreasing relative risk aversion, large risks, associated with large percentage losses, are those most likely to be imsured. Therefore, large risks are those that ought to be compensated.

The theoretical foundation that we have developed does not, however, provide unbridled support for an expanded role for government compensation. Compensation is costly in an economic sense, measured by the administrative and other economic costs associated with the payment of compensation. Administrative costs can be substantial, especially when a broad compensation rule is implemented. Finally, a compensation system that implicitly subsidizes one forn of land use relative to another can add distortions to land use decisionmakmg. These distortions are more severe than the possible distortions due to uninsured risk. We are not prepared at this point to work out the details necessary to apply our rule for determining when compensation should be paid, nor have we discussed in any detail whether a legislatively constituted compensating body is appropriate. We do hope, however, that the methodological issues raised in this Article will move us inucl closer to a workable solution to this important social question. 


\section{Appendix \\ The Provision of Unfair Insurance}

When a risk-averse individual is presented with the opportunity to buy actuarially fair insurance, he will fully insure against all risks. However, when the insurance is actuarially unfair, a risk-averse individual will respond in a more complicated manner. Individuals might fully insure against soine risks, partially insure against others, and not msure at all against still other risks. In this appendix, we show that this outcome, rather than full imsurance agamst all risks, is likely in a wide variety of circuinstances. The discussion that follows presuines a substantial background in economics. Nevertheless, the treatinent has been simplified to be as accessible as possible.

\section{A. The Model}

Assume that an individual faces two possibilities. With probability $q$, he will suffer a loss that reduces his wealth by an anount $l$, and with probability $1-q$, the loss will not take place and he will lose nothing. In the event of the loss, the individual's wealth is $w-l$, otherwise his wealth is $w$.

The individual nnay buy insurance to protect himself froin the loss. If he buys an insurance policy, he pays a premium $p$ whether or not the loss takes place, and in return he receives a reward $r$ in the event that the loss occurs. With the insurance policy, his wealth in the event of a loss is $w-p-l+r$, while if no loss takes place, his wealth is $w-p$.

\section{B. Actuarially Fair Insurance}

Typically, the individual has inany different policies to choose from. For example, he may be able to purchase an actuarially fair insurance policy. In an actuarially fair policy, the premiun is equal to the expected reward, so that the average net payout is 0 . The policy takes im $p$ dollars with certainty, and pays out $r$ dollars with probability $q$ and nothing with probability $1-q$. The average gross payout is thus $q r$, and the average net payout is $q r-p$. Thus an insurance policy in this simple model is actuarially fair if $p=q r$.

Suppose that the individual can purchase any actuarially fair policy he wants. A risk-averse individual will purchase insurance in order to equalize his net wealth regardless of loss. In other words, he will choose a policy such that $w-p=w-p-l+r$. This result is achieved when the reward exactly equals the loss; then, the individual fully in- 
sures. To see why net wealth will be equated in both circumstances, we study the individual's choice problem:

$$
\begin{aligned}
& \max [(1-q) U(w-p)+q U(w-p-l+r)] \\
& p, r \\
& \text { s.t. } p=q r
\end{aligned}
$$

The individual maximizes expected utility, and we assume that he is risk averse (i.e., $U^{\prime}>0, U^{\prime \prime}<0$ ). This problem is equivalent to (substituting for $p$ in (1)):

$$
\max [(1-q) U(w-q r)+q U(w-l+(1-q) r)] \text {. }
$$

The problem is solved by choosing the actuarially fair policy with reward $r^{*}$ satisfying the first-order condition for maximization:

$$
-q(1-q) U^{\prime}\left(w-q r^{*}\right)+q(1-q) U^{\prime}\left(w-q r^{*}-l+r^{*}\right)=0 .
$$

This equation is satisfied precisely when $U^{\prime}\left(w-q r^{*}\right)=$ $U^{\prime}\left(w-q r^{*}-1+r^{*}\right)$. Simce the hypothesis of risk aversion implies that $U^{\prime}$ is strictly positive, the only solution is $r^{*}=l$.

\section{Actuarially Unfair Insurance}

It is now possible to study the relationship between the individual's demand for insurance and the cost of insurance in a world in which insurance is actuarially unfair. Our broad conclusion is that in a world of unfair insurance, only individuals who are substantially averse to risk will choose to imsure, and only under a certain set of conditions will they fully insure.

Assume that the insurance policies to be offered to the individual have premiums which satisfy the following relationship: $p=a+b r$, where $a$ and $b$ are nonnegative constants. In the policies that are considered here, $a$ represents a fixed cost of writing any imsurance contract, while $b$ represents the margmal cost of increasing the reward an extra dollar. With actuarially fair insurance, $a=0$ and $b=q$, and the individual will choose to insure fully. With actuarially unfair insurance, we might expect either $a>0, b>q$, or both. (Recall that $q$ is the probability of loss, and for a $\$ 1$ reward, $q$ is the expected loss to be insured. Thus when $b=q$, the marginal cost of insurance is equal to the margmal benefit.) We would not expect individuals to be offered actuarially fair pohicies as a general rule, because there are costs of administration. Moreover, moral hazard or adverse selection might also affect the cost.

In the more general case currently under consideration, the solution to problem (1) comes out differently. The necessary condition satisfied by $r^{*}$ is, if $r^{*}>0$ :

$$
-b(1-q) U^{\prime}\left(w-a-b r^{*}\right)+(1-b) q U^{\prime}\left(w-a-b r^{*}-l+r^{*}\right)=0 .
$$


However, in the event that no insurance is purchased, the fixed cost $a$ and the marginal cost $b$ are not paid and the expected utility becomes:

$$
(1-q) U(w)+q U(w-l) \text {. }
$$

Since the analysis is shightly more complicated when fixed costs are present, we will begin by considering first the case where $a=0$. The first-order condition becomes (solving froin (2) with $a=0$ ):

$$
U^{\prime}\left(w-b r^{*}\right)=[(1-b) q] /[b(1-q)] U^{\prime}\left(w-b r^{*}-l+r^{*}\right) .
$$

Suppose that $b>q$. Then the first-order condition implies that $U^{\prime}\left(w-b r^{*}\right)<U^{\prime}\left(w-b r^{*}-l+r^{*}\right)$. The hypothesis of risk aversion says that $U^{\prime}()$ is decreasing in its argument $\left(U^{\prime \prime}<0\right)$, and we can conclude that $w-b r^{*}>w-b r^{*}-l+r^{*}$, so $l>r^{*}$. When $b>q$ the individual buys less than full insurance. If $b<q$, the same arguments imply that the individual overinsures. He buys a policy that pays out inore than the loss in the event of an accident. Thus, one can make a case on efficiency grounds for partial compensation if the inarginal cost of providing insurance is greater than the marginal benefit of that insurance.

Now consider the case in which the writing of policies has a fixed cost. First consider the case in which $b=q$. Assuming that any insurance is bought, the best possible amount to buy is the reward $r^{*}$ which satisfies equation (2). When $b=q$ the equation becomes:

$$
U^{\prime}\left(w-a-q r^{*}\right)=U^{\prime}\left(w-a-q r^{*}-l+r\right) .
$$

The fact that $U^{\prime}()>0$ implies that the net wealth in the two circuinstances must be equal, and so $r^{*}=l$. If the individual chooses to buy insurance at all, he will fully insure. In this case he will have a certain net income of $w-a-q l$. But this may not be better than buying no insurance, bearing all the risk, but not paying out $a$. The individual will purchase a positive amount of imsurance if:

$$
U(w-a-q l)>(1-q) U(w)+q U(w-l) .
$$

The number $a^{*}$ which just satisfies equation (3) plays an important role in the analysis of msurance. It is called the risk premium for the gamble faced by the individual. It ineasures how mucl the individual would be willing to pay for the privilege of purchasing actuarially fair insurance. The risk premium gives us the answer to our problem. If $a$ $<a^{*}$, the individual will fully insure. If $a>a^{*}$ he will not insure, and he will bear all of the risk. Thus the magintude of $a$ does not affect the size of the optimal policy at the margin, but only in this all-or-nothing maimer. This result motivates a substantial portion of the discussion in the text. It suggests that it will be efficient under a specific set of conditions for the governing body to insure fully individuals against sone risks while providing no insurance agamst others.

Fimally consider the case of the arbitrarily chosen $b$. If the individual chooses to purchase insurance at all, the optimal amount is the solution $r^{*}$ to equation (2). If $b>q$, the same reasoning applied before 
leads to the conclusion that $w-a-b r^{*}>w-a-b r^{*}-l+r^{*}$, so that $l>r^{*}$. The individual will not fully insure. But the individual will purchase a positive amount of insurance only if:

$(1-q) U\left(w-a-b r^{*}\right)+q U\left(w-a-b r^{*}\right)-l+r^{*}>(1-q) U(w)+q U(w-l)$. (4)

Define $a^{*}$ to be fixed cost $a$ that just makes the equation (4) hold with equality:

$(1-q) U\left(w-a^{*}-b r^{*}\right)+q U\left(w-a^{*}-b r^{*}-l+r^{*}\right)=(1-q) U(w)+q U(w-l) .(5)$

As before, for a given $b$, the consumer will purchase $r^{*}$ units of insurance if $a<a^{*}$. Otherwise, the individual will purchase no insurance. To see how $a^{*}$ depends upon $b$, differentiate equation (5) with respect to $b$, and solve to get:

$$
d a^{*} / d b=-r^{*}<0
$$

If the insurance policy is actuarially unfair, with $b>q$, the individual will tolerate less of a fixed cost than he would for the provision of fair insurance-that is, $a^{*}$ will be smaller than the risk premium. If the policy is nore than fair, with $b<q$, the individual will tolerate a higher fixed cost than in the fair insurance case. 